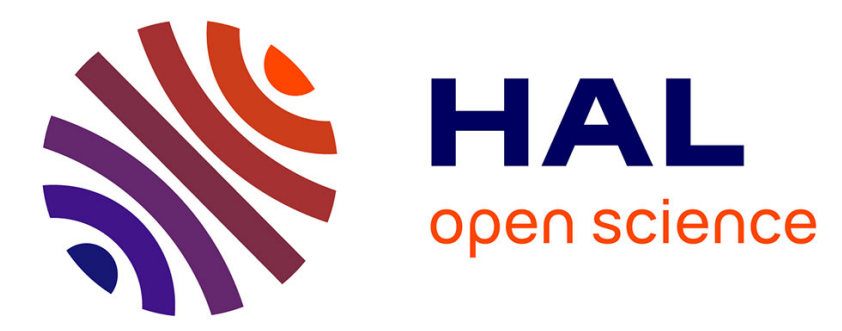

\title{
PYROLYSIS IN POROUS MEDIA: PART 2. NUMERICAL ANALYSIS AND COMPARISON TO EXPERIMENTS
}

Nicolas Gascoin, Luigi Romagnosi, Ivan Fedioun, Johan Steelant, Guillaume Fau, Marc Bouchez

\section{To cite this version:}

Nicolas Gascoin, Luigi Romagnosi, Ivan Fedioun, Johan Steelant, Guillaume Fau, et al.. PYROLYSIS IN POROUS MEDIA: PART 2. NUMERICAL ANALYSIS AND COMPARISON TO EXPERIMENTS. Journal of Porous Media, 2013, 16 (9), pp.857-873. hal-00868587

\section{HAL Id: hal-00868587 https://hal.science/hal-00868587}

Submitted on 2 Oct 2013

HAL is a multi-disciplinary open access archive for the deposit and dissemination of scientific research documents, whether they are published or not. The documents may come from teaching and research institutions in France or abroad, or from public or private research centers.
L'archive ouverte pluridisciplinaire HAL, est destinée au dépôt et à la diffusion de documents scientifiques de niveau recherche, publiés ou non, émanant des établissements d'enseignement et de recherche français ou étrangers, des laboratoires publics ou privés. 


\title{
Pyrolysis in Porous Media: Part 2.
}

\author{
Numerical Analysis and Comparison to Experiments. \\ Shortened Title (Running Head) : Numerical and Experimental Pyrolysis in Porous Media \\ Nicolas Gascoin ${ }^{1}$ \\ ENSIB, Bourges, 18000, France \\ Luigi Romagnosi \\ University of Orléans, Bourges, 18000, France \\ University of Rome, La Sapienza, Rome, 00184, Italy \\ Ivan Fedioun \\ Centre National de la Recherche Scientifique, Orléans, 45071, France \\ Johan Steelant \\ ESA-ESTEC, Noordwijk, 2200AG, The Netherlands \\ Guillaume Fau \\ University of Orléans, Bourges, 18000, France \\ Marc Bouchez \\ MBDA-France, Bourges, 18000, France
}

Only limited studies are available experimentally to investigate hydrocarbon fuel pyrolysis, which can be of practical interest for the active cooling of head loaded components in aerospace vehicles such as combustors in rocket engines. The numerical simulation is an additional way to investigate the related phenomena (heat and mass transfer with chemistry). After a first code validation with experiments based upon inert gases, the code is further extended towards permeation with reactive dodecane and a reasonable agreement is found. The experimental accuracy of the permeability's' determination is confirmed numerically to be within $\pm 30 \%$.

\footnotetext{
${ }^{1}$ Corresponding author. Tel.: +33 248238 473; Fax: +33 248238471.

E-mail address: nicolas.gascoin@ensi-bourges.fr (N. GASCOIN; ENSIB, 88 Boulevard Lahitolle, 18000 Bourges, FRANCE).
} 
$9 \quad \bar{c}_{p}=$ heat capacity at constant pressure $\left(\mathrm{J} \cdot \mathrm{mol}^{-1} \cdot \mathrm{K}^{-1}\right)$

$10 C_{2}=$ inertial resistance factor $\left(\mathrm{m}^{-1}\right)$

$11 E_{A}=\operatorname{activation}$ energy $\left(\mathrm{J} \cdot \mathrm{mol}^{-1}\right)$

$12 \Delta H=$ enthalpy of reaction $\left(\mathrm{J} \cdot \mathrm{mol}^{-1}\right)$

$13 k_{\text {eff }}=$ effective thermal conductivity of the medium $\left(\mathrm{W} \cdot \mathrm{m}^{-1} \cdot \mathrm{K}^{-1}\right)$

$14 K_{D / F}=$ Darcian $\left(\mathrm{m}^{2}\right) /$ Forchheimer's coefficients $(\mathrm{m})$

$15 \dot{m}=$ mass flow rate $\left(\mathrm{kg} \cdot \mathrm{s}^{-1}\right)$

$16 P=\operatorname{pressure}(\mathrm{Pa})$

17

18

$19 \vec{v}=$ velocity vector $\left(\mathrm{m} \cdot \mathrm{s}^{-1}\right)$

20

21 analysis of the fuel pyrolysis and of the products' formation.

17. $Q_{R}=$ heat of reaction

(J.mol $\left.{ }^{-1}\right)$

$S_{i}=\operatorname{sink} \operatorname{term}(\mathrm{Pa})$

$Y_{j}=$ species mass fraction ()

$\alpha=$ permeability factor $\left(\mathrm{m}^{2}\right)$

$\mu=$ dynamic viscosity (Pa.s)

$\rho_{f / s}=$ density of the fluid $/$ solid $\left(\mathrm{kg} \cdot \mathrm{m}^{-3}\right)$

Numerically it is shown that this accuracy is due to strong flow spatial heterogeneities. The border effect of the test cell is found to be related to the permeable medium thickness whereas the temperature field is correlated to the reaction zone. Two different kinetic mechanisms are used to investigate the chemistry effect on the heat and mass transfer. They provide also a better 


\section{Introduction}

Studying porous flow is of interest in numerous fields of research and more specifically in the present framework of active cooling intended to be used on highly thermally loaded structures (Langener et al., 2008; Kuhn and Hald, 2008, Gascoin et al. 2012a, Yuki et al., 2010). Transpiration cooling through a porous structure is highly efficient as shown by Langener et al. (2011) and by Cheuret et al. (2011). This technology is found in rocket engines and chambers for example (Arnold et al., 2009; Kanda et al., 1994). This reduces the temperature of the solid permeable materials used to sustain the large heat load encountered by the combustor (Fau et al., 2011; Gascoin and Gillard, 2012). Carbon- or oxide-based composite materials are preferred for thermal, mechanical and chemical reasons (Bouchez and Beyer, 2009). In addition, when using the fuel as a coolant, the so-called regenerative technique, a pyrolysis is generally encountered for fluid temperature over $800 \mathrm{~K}$ (Gascoin, 2010). This generates endothermic reactions which contribute to the heat flux absorption. The formation of a thin film inside the combustion chamber, the so-called film cooling technique, is another parameter participating in the structure cooling (Arnold et al., 2009). The main drawbacks of these coupled solutions are the multiphysics' interactions which modify transiently the permeabilities of the structure and the cooling efficiency (Fau et al., 2011; El-Amin et al., 2013). The fuel cracking produces light and heavy species which are coke precursors (Gascoin et al., 2008a). The formation of solid particles modifies the fluid filtration and consequently the heat and mass transfers (Gascoin et al., 2012b).

Experimental chemical studies generally focus on the fuel pyrolysis as a function of the fuel nature, of the operating conditions or of the reactor's nature (Pant and Kunzru, 1996; Zeppieri et al., 2000; Herbinet et al., 2007; Yu and Eser, 2000; Edwards et al., 2006). Some numerical works are also available (Gascoin et al., 2011; Slavinskaya et al., 2009, Shahnazari and Vahabikashi, 2011). Other studies are related to the heat and mass transfers (Younis, 2010; Jaballah et al., 
12012 ) involved in the active cooling by means of computing (Lina et al., 2009) and of testing

2 (Langener et al., 2008; Kuhn and Hald, 2008). Nevertheless, there is only rare studies aiming at 3 grouping both experimental and numerical approach to provide a deep analysis of the 4 multiphysics' phenomena (thermal, fluid, mechanical and chemical points) (Fau et al., 2011, 5 Romagnosi et al., 2012). The complementarity of these two kinds of work is due to the fact that 6 numerical studies still face strong difficulties in solving massively detailed kinetic mechanism 7 and in handling porous flow with microscopic description over full length scales and over long 8 timescales (Jaber and Ziad Saghir, 2011). On the opposite, it is difficult experimentally to 9 determine microscopic or local parameters such as the temperature or the species concentration 10 and to measure the heat flux or the residence time (Khan and Reddy Gorla, 2010; Elgazery, 11 2012; Zamanian et al., 2012). For this reason, a European collaboration has been settled to establish a numerical modelling of reactive porous flow with semi-detailed chemistry and taking the other physical parameters into account (heat and mass transfers, multi-diffusion, porous flow modelling, compressibility effects, real fluid properties) (Romagnosi et al., 2012). In this previous work (Romagnosi et al., 2012), the authors have proposed a numerical simulation of an experimental test device, the so-called permeation test cell. Using commercial Ansys/Fluent software for portability reasons, a parametric study has been generated to determine the physical and chemical effects of the different modelling options. Some experimental comparisons on inert gas flow were performed and the simulation of reactive flow was the final step. A large state of the art on fluid permeation, particularly in case of chemical reactions, is given in (Romagnosi et al., 2012).

Thanks to this preceding work, the authors now aim at comparing the numerical results to the experimental ones on dodecane pyrolysis cases in order to determine the model sensitivity and 
accuracy. Numerical data are of major importance for the analysis of the experimental results. Dodecane is used to compare with experiments but methane should be used in latter steps for rocket combustors application.

\section{Material and Methods}

\section{A. Numerical simulation}

The numerical code features have been extensively presented and discussed previously (Romagnosi et al., 2012). A 2-D geometry with 14,242 structured cells (Figure 1) models the test cell to be detailed in next section. The solver handles compressible steady-state configurations. The Navier-Stokes equations (Eq. 1 to Eq. 3) are modified taking into account the porosity effect of the sample, the consequent pressure drop through the medium and the effective thermal conductivity of the porous zone (fluid plus porous material). The Forchheimer's equation is used to simulate the pressure drop via a sink term in the momentum equation (Eq.4), where $\alpha$ and $\mathrm{C}_{2}$ are respectively $2.061 \cdot 10^{-13} \mathrm{~m}^{2}$ and $4924000 \mathrm{~m}^{-1}$ (obtained experimentally by You et al. (2009)).

The pressure-based solver guaranties a faster and stable convergence. The boundary conditions correspond to constant: inlet mass flow rate, pressure outlet and wall temperature. The conditions measured experimentally are used directly in the software to simulate identical test cases. The simulation settings change depending on the case under study: nature of the fluid 
1 (nitrogen or kerosene surrogate), operating temperatures (from $300 \mathrm{~K}$ to $1200 \mathrm{~K}$ ) and mass flow

\section{Figure 1 should be placed here.}

A detailed kinetic mechanism (56 species and 289 reactions) simulates the dodecane pyrolysis (You et al., 2009). The present authors have reduced this mechanism (15 species, 20 reactions) for computation cost reason with limited loss of accuracy. Two primary reactions (" 1 " and "2" in Table 1) allow the cracking of dodecane producing ethylene $\left(\mathrm{C}_{2} \mathrm{H}_{4}\right)$ and two radicals but-1-yl $\left(\mathrm{pC}_{4} \mathrm{H}_{9}\right)$ and n-propyl $\left(\mathrm{nC}_{3} \mathrm{H}_{7}\right)$. These two reactions controlling the pyrolysis process correspond to a high activation energy $\left(\approx 3.68 \cdot 10^{5} \mathrm{~J}^{\mathrm{mol}}{ }^{-1}\right)$. The sensitivity analysis (You et al., 2009) for $\mathrm{n}$ dodecane pyrolysis shows that the fuel conversion rate is controlled by C-C fission of ndodecane and $\mathrm{H}$-abstractions by $\mathrm{H}$ and $\mathrm{CH}_{3}$. So the present authors primary considered adding at least the reactions allowing the formation of these two radicals (monatomic hydrogen via backward reaction "4" and "5" and methyl radical via " 12 "). The presence of $\mathrm{H}$ and $\mathrm{CH}_{3}$ accelerates the pyrolysis rate via propagation reactions for reactions " 6 " $\rightarrow$ " 10 " and " 13 " $\rightarrow$ "17". The ramification is indirect via dissociation of light species as hydrogen $\mathrm{H}_{2}$ (reaction "11") and ethane $\mathrm{C}_{2} \mathrm{H}_{6}$ (reaction "20"). The reactions involving directly the interaction between the ndodecane and the radicals $\mathrm{H}$ and $\mathrm{CH}_{3}$ include both $\mathrm{H}$-abstraction and $\beta$-scission of n-C12-alkylradical $\left(\mathrm{C}_{12} \mathrm{H}_{25}\right)$.

By comparing this reduced mechanism under perfectly stirred reactor configurations at 3.5 MPa with the original one (You et al., 2009) and with a very detailed one (271 species and 1449 reactions) (Herbinet et al., 2007), the present reduced scheme is judged adequate for the specific conditions used in this paper despite important discrepancies (Figure 2). The overall performance 
is generally poor but they are acceptable in the specific thermal range $900 \mathrm{~K}-1200 \mathrm{~K}$ at $3.5 \mathrm{MPa}$ and for residence time comparable to those in the system. At $900 \mathrm{~K}$ and after $0.7 \mathrm{~s}$ of simulation (which is roughly the residence time found later in the cell, see section C), the conversion of dodecane is adequately simulated by the reduced scheme (Figure $2 \mathrm{a}$ ) while the initial detailed one of You et al. (2009) presents a factor 2 compared to the accurate reference mechanism of Herbinet et al. (2007). A factor 2 is found on ethylene between the reference and the reduced scheme, which shows that the products distribution is predicting with a limited accuracy. After $10 \mathrm{~s}$ at $900 \mathrm{~K}$ (constant pressure of 3.5 MPa), ethylene and ethane are reproduced fairly contrary to some species like hexene (Figure $2 \mathrm{~b}$ ). At $1200 \mathrm{~K}$ and $3.5 \mathrm{MPa}$, after $10 \mathrm{~s}$, the discrepancies are still important between the reference and the reduced mechanisms, mainly concerning the methane formation while the original mechanism of You et al. (2009) gives satisfactory results. The major compound found in the reduced mechanism is ethylene (Figure 2c). Looking at the dynamics of the pyrolysis (Figure $2 \mathrm{~d}$ ), the original mechanism presents a shift on the log- time scale compared to the reference mechanism. The reduced mechanism presents a mean behaviour around the reference one. As a consequence, in order to perform first kinetic computations within 2-D geometry, the reduced mechanism is used but one should pay attention to the limited accuracy in terms of products formation. This mechanism has been optimised for representing the dodecane consumption and it cannot accurately represent the formation of radicals, of light species like hydrogen and of middle-weight species like hexene. This reduced mechanism is a compromise which should be later improved by increasing the number of species and of reactions and, as a consequence, the computation cost.

\section{Table 1 should be placed here.}

Figure 2 should be placed here. 


\section{B. Experimental setup}

The COMPARER pyrolysis test bench is used to pressurize and to heat the fuel under flow conditions (Gascoin et al., 2008b). Its main characteristics are the following:

- Maximum operating conditions: $1800 \mathrm{~K}, 8.0 \mathrm{MPa}, 600 \mathrm{mg} \cdot \mathrm{s}^{-1}$ for liquid fluid and $6000 \mathrm{mg} . \mathrm{s}^{-1}$ for gas

- Chemical analysis: Gas Chromatograph/Mass Spectrometer-Flame Ionisation DetectorThermal Conductivity Detector with10 sampling loops for a posteriori quantitative analysis, Fourier Transform Infra Red spectrometer (inline direct quantitative analysis)

- Sensors: 5 mass flow rates, 5 pressure transducers, over $10 \mathrm{~K}$-type and R-type thermocouples with data acquisition system (16 bits, 48 channels, $0.1 \mathrm{~Hz}$ ). This low frequency $(0.1 \mathrm{~Hz})$ is due to the limitations of the data acquisition system to gather the 48 channels at the same time.

A permeation test cell contains the porous sample (Figure 3). This cell is inserted inside the furnace of the COMPARER bench and it is connected to the fluid supply system and to the appropriate sensors. The permeable medium bounds the cell in two high and low pressure chambers (upstream and downstream to the porous medium respectively). These chambers are noted HPC and LPC in this paper. An inlet pipe provides the fuel into the system. This cell is connected to a dynamic sampling system to get hot pressurized samples at three location points in the cell. These samples are later cooled and chemically quantified by the GC/MS-FID-TCD. This allows having the longitudinal pyrolysis profile of the fuel under given operating conditions. The FTIR analysis provides real-time quantification at the process outlet on the gas products only after having cooled and expanded the pyrolysis mixture at ambient conditions. 
The permeable medium can be changed. In the present work, an isotropic stainless steel material is preferred to composite one to avoid considering complex microstructure (fibres, layers). It is characterized by a porosity around $30 \%$ (experimental measure through the Archimede's principle and confirmed by SEM images), a grain diameter of $14.1 \mu \mathrm{m}$ and a pore diameter of $4.1 \mu \mathrm{m}$ (Gascoin, 2011). Further geometrical information can be found in (Romagnosi et al., 2012; Gascoin, 2011).

Figure 3 should be placed here.

\section{Fuel pyrolysis analysis}

\section{A. Preliminary validation on inert test cases and first experiments analysis}

Nitrogen is injected with constant mass flow rate and the inlet pressure is $2.5 \mathrm{MPa}$. The validation is made on the pressure drop through the porous material. Several temperatures have been tested from $300 \mathrm{~K}$ to $600 \mathrm{~K}$. The thermal conductivity of the stainless steel - nitrogen system $\left(k_{e f f}\right)$ is evaluated as a function of temperature using an averaged method between Parallel model and Maxwell Upper Limit (Travajno and Helwig, 2011).

The simulations performed with the initial $\mathrm{C}_{2}$ value presented some discrepancies compared to the experiments. Thus, the authors have corrected the $\mathrm{C}_{2}$ value by a multiplication factor of 1.25 (new $\mathrm{C}_{2}=6155000 \mathrm{~m}^{-1}$ ) because the Forchheimer accuracy is $\pm 30 \%$ (Gascoin, 2011). As a result, the computations are in good agreement with the experimental results (Figure 4). Note that, since the Forchheimer's coefficient is linked to the square of the velocity, the changes in $\mathrm{C}_{2}$ have a negligible effect on the pressure drop for low mass flow rates.

Figure 4 should be placed here.

The numerical simulation interest is clear because it can help validating the permeabilities values and understanding the reasons of any possible error. For example here, the complex 
velocity and pressure field upstream to the porous medium (Figure 5) generates a recirculation zone, which makes the pressure measurements sensitive to the spatial position. This impacts the experimental estimation of $\mathrm{K}_{\mathrm{D}}$ and $\mathrm{K}_{\mathrm{F}}$. As a consequence, it is wanted to verify how the pressure measures are appropriate for the kerosene experiments. A similar cold simulation has thus been done using kerosene surrogate (n-dodecane), which is liquid at ambient temperature $\left(\mathrm{T}_{\text {inlet }}=300\right.$ $\mathrm{K})$. The mass flow rate is $65 \mathrm{mg} \cdot \mathrm{s}^{-1}$. The density is fixed at $746 \mathrm{~kg} \cdot \mathrm{m}^{-3}$ and the inlet pressure is 3.5 MPa. The high viscosity of the kerosene $\left(\mu=1.37 \cdot 10^{-3}\right.$ Pa.s $)$ and its low injection velocity bounds the recirculation zones at the cell inlet between $\mathrm{x} \approx-0.025 \mathrm{~m}$ and $\mathrm{x} \approx-0.018 \mathrm{~m}$ (Figure 6). This means that the flow invests the porous medium almost uniformly and, in this case, it is not so important where the pressure sensors are located.

Figure 5 should be placed here.

Figure 6 should be placed here.

\section{B. Validation with reactive dodecane experiment}

The experiments were achieved by Fau et al. (2011) at $3.5 \mathrm{MPa}$ with a varying mass flow rate between $60 \mathrm{mg} . \mathrm{s}^{-1}$ and $65 \mathrm{mg} . \mathrm{s}^{-1}$ due to stability problems. The setup furnace temperature was $900 \mathrm{~K}$ and the temperature experimentally measured at the outside wall of the cell was $890 \mathrm{~K}$. The fluid temperature measured inside the test cell (in the high pressure chamber) was $820 \mathrm{~K}$. Longitudinal thermal gradients measured experimentally were lower than $10 \mathrm{~K}$ roughly between two positions: $3 \mathrm{~mm}$ before the porous medium and $3 \mathrm{~mm}$ after, following the main fluid flow direction. The experiments (Figure 7) show a high dodecane content upstream to the porous medium (in the High Pressure Chamber) and inside the porous medium (83.3 wt.\% and 81 wt.\% respectively) while a mass fraction around 52 wt.\% has been found downstream, in the Low 
Pressure Chamber. The experimental quantification of the main species considered by the reduced mechanism (Table 1) are summarized in Figure 7 for comparison purpose.

\section{Figure 7 should be placed here.}

Numerically, it is difficult to represent all the experimental fluctuations. As a consequence, several test cases have been computed (Table 2). For all of them, the pressure is $3.5 \mathrm{MPa}$, the fluid is the dodecane and the reduced kinetic mechanism presented above is used (15 species, 20 reactions). The real gas model enables computing the fluid properties, which requires knowing the species critical properties such as the critical temperature, pressure and volume and the acentric factor. For the first case (Table 2), minimum (Figure 8a) and maximum (Figure 8b) mass fractions at several longitudinal $\mathrm{x}$-axis positions are given for a selection of species. The upstream zone presents a low dodecane content (Figure 8a) due to the recirculation in which quasi static fluid is found. Hexene, pentene and ethylene are found in high proportion (Figure $8 b)$. Comparing these results with the second case (Figure $8 \mathrm{c}, \mathrm{d}$ ) clearly shows that the higher temperature increases the dodecane pyrolysis because the minimum species quantities are much higher for this second case (Figure 8c) compared to the first one (Figure 8a). As a consequence, the maximum dodecane quantities are lower for this second case (Figure 8d). The same major products are found. The discrepancies between the two numerical cases are attributed in priority to the heat transfers but the mass flow rate also plays a role which will be investigated in section C.

The dodecane mass fraction at the cell outlet of case $2(\mathrm{x}=13 \mathrm{~mm}$ just before the outlet pipe) is found between $10 \mathrm{wt} . \%$ and $25 \mathrm{wt} . \%$, which is lower than the experimental value. For the case 1, the extreme values are $15 \mathrm{wt} . \%$ and $85 \mathrm{wt} . \%$. This includes the experimental value of $52 \mathrm{wt} . \%$. Consequently, the test conditions are very important and slight changes $(820 \mathrm{~K}$ to $890 \mathrm{~K}$, in 
conjunction with mass flow rate variations) generate different results which are difficult to validate with the experiments. In addition, the kinetic mechanism has a role in the disagreement found between the numerical and the experimental data. The scheme has been tested (section II.A) and its accuracy is average. The pyrolysis process and the fluid dynamics are closely related because the density changes with the chemical composition and this affects the dynamics into the cell (residence time' and heat transfers' consequence). Hence, the kinetic mechanism becomes a critical parameter and adopting a detailed scheme is preferable.

\section{Table 2 should be placed here.}

\section{Figure 8 should be placed here.}

Finally, because the case 1 is judged to be closer to the experimental conditions, the corresponding results are compared to the experimental ones (Figure 9). Three zones are defined: before the porous medium (for a position $\mathrm{x}=-3 \mathrm{~mm}$ ), inside the porous zone $(\mathrm{x}=1.5 \mathrm{~mm})$ and at the process outlet $(\mathrm{x}=30 \mathrm{~mm})$. The mean conversion rate is over-estimated in the HPC (Figure 9a) and in the porous zone (Figure 9b) by the computations because the spatial average over the $\mathrm{y}$-axis for each $\mathrm{x}$-axis position takes the stagnation zones near the wall into account while the experimental sampling locations are closer to the central axis of the cell. The agreement is much better at the bench outlet (Figure 9c). Nevertheless, due to the uncertainties presented above, there are too much parameters acting on the system to be certain that the numerical simulation is validated. This is particularly due to the kinetic scheme. The hexene content is overpredicted by the computations because the secondary mechanism of this species is not considered and it cannot be consumed. This explains the low quantities which are found for the light species such as ethane or methane. In addition, additional sources of discrepancies can be mentioned; with the most likely: uncertainty regarding the sampling probe position, experimental uncertainties of 
calibration and of analysis, 2-D cell effect and kinetic scheme limitations. Their quantitative effects are difficult to investigate.

Figure 9 should be placed here.

To verify the effect of the chemistry, a two-steps kinetic scheme (Romagnosi et al., 2012) is used to redo the same test case 2 . A reduction of only $17 \mathrm{~K}$ of the fluid temperature between the inlet and the outlet is observed and the net heat flux at the wall is $3.2 \mathrm{~W}$. This explains the very low pyrolysis rate at the outlet (remaining dodecane mass fraction of 98 wt. \%). Consequently, the experimental values (pyrolysis rate of $48 \mathrm{wt} . \%$ ) are bounded by the numerical ones obtained with two different kinetic schemes (pyrolysis rate of 80 wt. \% for the detailed scheme and of 2 wt. $\%$ for the 2 -steps scheme). The lower reactivity of the simplified mechanism is due to the radicals, such as methyl and monatomic hydrogen, which are not in the two-steps mechanism while they increase the reaction rate.

\section{Use of the numerical simulation to investigate the reactive porous flow}

Considering the third case (Table 2), the conversion rate of dodecane reaches 94 wt. $\%$ at the cell outlet (Figure 10a). A maximum thermal decrease of about $300 \mathrm{~K}$ is found (Figure 10b). This temperature fall is directly related to the enthalpy of reaction (Figure 10c), thus to the reaction zone. This point is particularly important because following the temperature would give precious indication on the chemistry. This is confirmed by looking at the molecular weight profile (Figure 10d). Such a result demonstrates the benefit of the computations compared to the experiments. This also shows that the recirculation zones, where the temperature is maximum (at $\mathrm{y}=0.008 \mathrm{~m}$ and for $\mathrm{x}=-0.024 \mathrm{~m}$ and $\mathrm{x}=0.013 \mathrm{~mm}$ ), do not really participate to the pyrolysis. This is satisfactory when conducting pyrolysis in porous flow.

Figure 10 should be placed here. 
This information concerning in which part of the system does the pyrolysis take place can be completed. Looking at the fuel consumption along the cell following the streamline on the axis of symmetry, a fast dodecane cracking occurs immediately at the inlet of the cell due the high inlet temperature (Figure 11a). The dodecane mass fraction entering the HPC is about $72 \mathrm{wt} . \%$ and it is around 66 wt. $\%$ at the porous medium inlet. It is 55 wt. $\%$ at its outlet, 28 wt. $\%$ at the LPC outlet and 18 wt. $\%$ at the pipe outlet. This means that the porous medium only represent 11 wt. \% of the converted dodecane compared to the $82 \mathrm{wt} . \%$ which are converted in the entire system. Thus, the porous media is the place where about $14 \%$ of the pyrolysis activity takes place and its thickness $(3 \mathrm{~mm})$ corresponds to $4 \%$ of the total length of the system $(70 \mathrm{~mm})$. In terms of residence time, the porous medium represents less than $10 \%$. The slope of the curve giving the residence time shows that the fuel is slowed down in the LPC because the slope increases. The fuel velocity increases in the outlet pipe due to the cross-section reduction.

Since the experimental mass flow rate slightly fluctuates between $60 \mathrm{mg} . \mathrm{s}^{-1}$ and $65 \mathrm{mg} . \mathrm{s}^{-1}$, its effect has been investigated (case 3 and 4). The total residence time and its distribution are not so different (Figure 11b). Increasing the fuel mass flow rate decreases the pyrolysis rate at the outlet which means that the density and the residence time effect (acting similarly) have a lower impact than the convective heat transfers which increase $(80 \mathrm{wt} . \%$ and $72 \mathrm{wt} . \%$ of pyrolysis rate for cases 3 and 4 respectively). This discrepancy of about $10 \%$ is directly linked to the mass flow rate fluctuations of about $10 \%$. This demonstrates the direct effect of the fluid flow on the chemical parameters. Thus, simulating the experiments in which the flow rate varies is difficult numerically where the flow rate is fixed. This contributes to explain the disagreement found in section B.

Figure 11 should be placed here. 
The effect of the temperature (comparison of cases 1 and 4 ) on the chemistry is represented by Figure 12. The strong chemical differences regarding the 2-D dodecane content (Figure 12a, b) are directly related to the thermal conditions. The residence time distribution is similar for case 1 (Figure 12c) than for cases 3 and 4 (Figure 11). Nevertheless, the residence time is about three times higher in case 1 than in other cases. This demonstrates that the temperature impacts the chemistry and the density, so the residence time, but its importance is much higher. A temperature decrease increases the density and decreases the velocity through the mass conservation. Thus, the residence time is higher but this is not balanced by an increased convective heat flux. This spate of events is important to analyse the results and this cannot be done experimentally, which shows the good complementarity of both tools.

Figure 12 should be placed here.

\section{Specific analysis of coupled phenomena in the porous medium}

Comparing the dodecane conversion at the inlet and at the outlet of the porous medium for the fourth case, a coupling between the fluid flow and the chemistry is found (Figure 13a). Close to the symmetric axis $(y=0 \mathrm{~mm})$, the flow speed is the highest and the conversion is limited. The chemical gradient is consequently low (68 wt. $\%$ to 60 wt. $\%$ ). However, for $\mathrm{y}=4 \mathrm{~mm}$ and higher, the fluid velocity decreases, the residence time and the heat flux increase (mass fraction difference at $\mathrm{y}=4 \mathrm{~mm}$ of $48 \mathrm{wt} . \%$ ). Thus, the pyrolysis is impacted by the border effect (wall of the cell). It is possible to plot it as a function of the x-axis, i.e. the porous medium thickness (Figure 13b). The Figure 13b shows that after $1 \mathrm{~mm}$ of porous flow, the wall impacts the flow on a distance of $1.5 \mathrm{~mm}$. As a consequence, the radius of the permeable sample should not be lower than $1.5 \mathrm{~mm}$. It should even be much more in order to limit its effect. The thicker the porous 
material in the present permeation test cell, the bigger should be the diameter in order to limit this border effect. This result is of major importance to design the experiments and to analyse the data. This is related to both dynamic and thermal boundary layers.

Figure 13 should be placed here.

Focusing on the porous zone, Figure 14 shows the profiles of pressure, of density, of temperature and of the axial velocity along the y-coordinate at the inlet and at the outlet surface of the porous medium. The pressure drop, due to the permeable sample, is $6800 \mathrm{~Pa}$ and it shows a uniform distribution on both sides of the porous zone. Although the pressure does not change in the crosswise direction (Figure 14a), the density decreases moving from the axis of symmetry toward the walls and from the upstream side to the downstream one (Figure 14b). This is directly due to the heat transfers (Figure 14c) and it acts on the fluid velocity (Figure 14d).

The spatial thermal gradient at the porous medium inlet presents a parabolic shape (Figure 14c) while it tends to be linear at the outlet. This could be due to the software assumptions considering equilibrium between solid and fluid. This may also be realistic in case of low speed flow (the conduction gets more important than the convection). In this latest case, it could be interesting to determine the length required by the fluid to present a complete linear profile. This would correspond to the thermal establishment length. Another interesting point is the location of the minimum velocity (Figure 14d). It is around $\mathrm{y}=0.005 \mathrm{~m}$ at the porous medium inlet and $\mathrm{y}=$ $0.007 \mathrm{~m}$ at the outlet. This minimum is spatially shifted due to the thermal or chemical phenomena. Non-reactive hot flow could help understanding the reason of such a speed shift. Thus, a similar test case without reactions has been achieved for comparison purpose (Figure 15). Different temperature and velocity profiles have been obtained in comparison with Figure $14 c, d$. The difference is attributed to the chemistry, which impacts the molecular weight profile. 
1 In addition, the heat transfer are modified because the endothermic effect of the pyrolysis for the reactive case decreases by about $40 \mathrm{~K}$ the temperature on the symmetry axis, at the sample inlet $(\mathrm{x}=0 \mathrm{~mm}$ ). The velocity profiles at the $0 \mathrm{~mm}$ and $3 \mathrm{~mm}$ positions are perfectly similar (the velocity amplitude only is shifted but not spatially). As a consequence, the modification of the minimum speed observed on Figure $14 \mathrm{~d}$ is due to the chemical reactions (and to its thermal effect) which modify the dynamic boundary layer.

Figure 14 should be placed here.

Figure 15 should be placed here.

\section{Conclusion}

The numerical simulation and the experimental tests are two complementary approaches, which are both suited for the study of fuel pyrolysis in porous media. Experimentally, all possible phenomena are taken into account with their intrinsic complexity and coupling, possibly under extreme conditions (1200 K and $6 \mathrm{MPa})$. Numerically, the heterogeneity profiles and the effect of the test bench itself (size and design of the permeation cell) have been observed finely despite the validity of the results is subject to the numerical, physical and chemical assumptions. A European Collaboration has been set up to provide a wide expertise in this field and to propose a validated numerical tool using detailed chemistry. A specific validation under no flow conditions has been first achieved for the chemistry since this is a major point in the numerical simulation of the reactive flow. After validation of the CFD simulation under inert conditions, its application to reactive test case presents average agreement with the experimental results. The computation method is judged promising. A modification by $25 \%$ of the Forchheimer's permeability tends to confirm the accuracy which was suggested experimentally ( $\pm 30 \%)$. The pressure sensor position is suggested to be of importance considering the pressure drop 
measures. At least qualitatively, the relationships between the heat and mass transfers and the chemistry have been considered. The effects of the choice of the kinetic schemes on the multiphysics' simulation have been presented. Detailed mechanisms are clearly necessary. The comparison between numerical and experimental data appears difficult due to the complexity of accurately representing the experimental conditions. The numerical simulation showed strong benefits in understanding a possible border effect related to the permeable sample thickness. The relationship between the temperature field and the reaction zone tends to demonstrate the major impact of chemistry in the heat flux repartition. As a future work, other detailed kinetic mechanisms should be tested to reinforce the chemical modelling and to determine which level of accuracy is necessary for the chemistry to have a good representation of the phenomena. The final aim is to consider methane for rocket engines application.

\section{Acknowledgments}

This work was supported by the ESA-ESTEC, Contract no.: 3-12861/09/NL/PA. The authors would like to sincerely thank F. Travajno and B. Le Naour from MBDA-France, P. Gillard, E. El Tabach and C. Strozzi from PRISME, D. Blanc and D. Courilleau from IUT Bourges, D. Davidenko from CNRS-ICARE Orléans, A. Ingenito from the University of Rome La Sapienza (Italy) and all the students involved in the projects head by I. Fedioun for their technical and scientific support involving the computations and the experiments.

\section{References}

Arnold R., Suslov D., Haidn O., Film Cooling of Accelerated Flow in a Subscale Combustion Chamber, Journal of Propulsion and Power, 25 (2), (2009) 443-451

Bouchez M., Beyer S., PTAH-SOCAR Fuel-Cooled Composite Materials Structure: 2009 Status, 16th AIAA/DLR/DGLR International Space Planes and Hypersonic Systems and Technologies Conference, October 2009, Bremen, Germany, AIAA 2009-7353 
Cheuret F., Steelant J. and Langener T., Numerical Investigation on Transpiration Cooling for Scramjet Applications using Different Coolants, in: 17th AIAA International Space Planes and Hypersonic Systems and Technologies Conference, April 11-14, 2011, San Francisco, USA, AIAA-2011-2379

Edwards T., DeWitt M. J., Shafer L., Brooks D., Huang H., Bagley S.P., Oña J.O., Wornat M.J., Fuel Composition Influence on Deposition in Endothermic Fuels, in: 14th AIAA/AHI Space Planes and Hypersonic Systems and Technologies Conference, Canberra, Australia, Nov. 6-9, 2006, AIAA 2006-7973

El-Amin M.F., Salama A., El-Amin A.A., Gorla R.S.R., Combined effect of thermal dispersion and variable viscosity of non-Darcy convection heat transfer in a fluid-saturated porous medium, J. Porous Media, vol. 16 (5), pp. 471-482, 2013.

Elgazery N., Numerical Simulation for Biviscosity Fluid Flow through a Porous Medium under the Effects of Variable Properties, Special Topics Rev. Porous Media, vol. 3 (1), pp. 1-11, 2012.

Fau G., Gascoin N., Gillard P., Bouchez M., Steelant J., Fuel Pyrolysis through Porous Media: Coke Formation and Coupled effect on Permeability., 17th AIAA International Space Planes and Hypersonic Systems and Technologies Conference, 11-14 Apr 2011, San Francisco, AIAA-2011-2206

Gascoin N., Gillard P., Bernard S., Bouchez M., 2008a, Characterisation of coking activity during supercritical hydrocarbon pyrolysis, Fuel Processing and Technology, 89 (12) (2008) 1416-1428.

Gascoin N., Abraham G., Gillard P., Bouchez M., 2008b, Test Bench Dimensioned by Specific Numerical Tool, Computer-Aided Chemical Engineering, 25 (2008) 835-840

Gascoin N., Etude et mesure de paramètres pertinents dans un écoulement réactif, Editions Universitaires Européennes, (2010) ISBN 978-613-1-50107-4

Gascoin N., Abraham G., Gillard P., Bouchez M., Real-time method for the identification and quantification of hydrocarbon pyrolysis products: Part II. Application to transient pyrolysis and validation by numerical simulation., Journal of Analytical and Applied Pyrolysis, Volume 91, Issue 2, July 2011, Pages 377-387

Gascoin N., High temperature and pressure reactive flows through porous media, International Journal of Multiphase Flow, 37 (2011) 24-35

Gascoin N., Gillard P., Dynamic Study of Coupled Heavy Hydrocarbon Pyrolysis and Combustion, Combustion Science \& Technology, 184 (2012) 1-18

Gascoin N., Fau G., Gillard P., Kuhn M., Bouchez M., Steelant J., 2012a,Comparison of Two Permeation Test Benches and of Two Determination Methods for Darcy's and Forchheimer's Permeabilities, Journal of Porous Media, vol. 15 (8), 2012, pp. 705-720. 
Gascoin N., Abraham G., Gillard P., Thermal and hydraulic effects of coke deposit in hydrocarbon pyrolysis process., 2012b, Journal of Thermophysics And Heat Transfer, Vol. 26 (1) Jan-Mar 2012, pp. 57-65

Herbinet O., Marquaire P.M., Battin-Leclerc F., Fournet R., Thermal decomposition of ndodecane : Experiments and kinetic modeling, Journal of Analytical and Applied Pyrolysis 78 (2007) 419-429

Jaballah S., Sammouda H., Bennacer R., Study of the mixed convection in a channel with porous layers using a thermal nonequilibrium model, J. Porous Media, vol. 15 (1), pp. 51-62, 2012.

Jaber, T.J., Ziad Saghir, M., Three-Dimensional Study Of Permeability Effect On Convection In Heterogeneous Porous Medium Filled With A Ternaryn Hydrocarbon Mixture, J. Porous Media, vol. 14 (4), pp. 305-315, 2011.

Kanda T., Masuya G., Wakamatsu Y., Kanmuri A., Chinzei N., Niino M., Effect of regenerative cooling on rocket engine specific impulse, Journal of Propulsion and Power, 10 (2) (1994) 286-288

Khan W.A., Reddy Gorla, R.S., Second Law Analysis For Mixed Convection In NonNewtonian Fluids Over A Horizontal Plate Embedded In A Porous Medium, Special Topics Rev. Porous Media, vol. 1 (4), pp. 353-359, 2010.

Kuhn M. and Hald H., Application of Transpiration Cooling for Hot Structures, RESPACE - Key Tech. for Reusable Space Sys., NNFM 98, (2008) 82-103

Langener T., von Wolfersdorf J., Laux T., Steelant J., Experimental Investigation of Transpiration Cooling with Subsonic and Supersonic Flows at Moderate Temperature Levels, 44th AIAA/ASME/SAE/ASEE Joint Propulsion Conference \& Exhibit 21 - 23 July 2008, Hartford, CT, AIAA 2008-5174

Langener T., von Wolfersdorf J., Steelant J., Experimental Investigations on transpiration Cooling for Scramjet Applications Using Different Coolants, AIAA Journal, 49 (7) (2011) 14091419.

Lina P., Guoqiang H, Peijin L., Experimental and Numerical Investigation of Active Cooling Ceramic Matrix Composite for Ramjet Propulsion System, in: 45th AIAA/ASME/SAE/ASEE Joint Propulsion Conference and Exhibit, Denver, Colorado, Aug. 2-5, 2009, AIAA-2009-5462

Pant K.K. and Kunzru D., Pyrolysis of n-heptane : kinetics and modeling, Journal of Analytical and Applied Pyrolysis 36 (1996) 103-120

Romagnosi L., Gascoin N., El-Tabach E., Fedioun I., Bouchez M., Steelant J., Pyrolysis in Porous Media: Part 1. Numerical model and parametric study, Energy Conversion and Management, 68 (2013), 63-73 
Shahnazari, M.R., Vahabikashi, A., Permeability Prediction Of Porous Media With Variable Porosity By Investigation Of Stokes Flowover Multi-Particles, J. Porous Media, vol. 14 (3), pp. 243-250, 2011.

Slavinskaya N.A., Zizin A., Aigner M., PAH and Soot Formation within Kerosene Pyrolysis, in: 47th AIAA Aerospace Sciences Meeting including The New Horizons Forum and Aerospace Exposition, Orlando, Florida, Jan. 5-8, 2009, AIAA-2009-1528

Travajno F., Helwig P., Calcul multiphysique dans une paroi poreuse, Master's Thesis, Supervisor: I. Fedioun, Polytech Orléans, France, 2010/2011.

You X., Egolfopoulos F.N., Wang H., Detailed and simplified kinetic models of n-dodecane oxidation: The role of fuel cracking in aliphatic hydrocarbon combustion, Proceedings of the Combustion Institute, 32 (1) (2009) 403-410. Mechanisms: http://ignis.usc.edu/Jet_Fuel_MechI.html

Younis, L.B., Cross-Flow Heat Exchanger Embedded Within A Porous Medium, J. Porous Media, vol. 13 (11), pp. 981-988, 2010.

$\mathrm{Yu}$ J. and Eser S., Supercritical-phase thermal decomposition of binary mixtures of jet fuel model compounds, Fuel 79 (2000) 759-768

Yuki K., Hashizume H., Toda S., Key Issues to Enable High Heat Flux Removal Exceeding $10 \mathrm{MW} / \mathrm{m} 2$ by Use of Metal Porous Media as a Latent Heat-Transfer Device, Special Topics Rev. Porous Media, vol. 1 (1), pp. 1-13, 2010.

Zamanian E., Mirjordavi N., Kazemeini M., Ghazanfari M.H., A New Empirical Correlation for Predicting Effective Molecular Diffusivity of Gas-Heavy Oil-Porous Media Systems, Special Topics Rev. Porous Media, vol. 3 (1), pp. 23-33, 2012.

Zeppieri S.P., Klotz S.D., Dryer F.L., Modeling concepts for larger carbon number alkanes : a partially reduced skeletal mechanism for n-decane oxidation and pyrolysis, Proceeding of the Combustion Institut 28 (2000) 1587-1595 
Figure 1 Computational domain layout.

Figure 2. 0-D numerical computations with three kinetic mechanisms at $900 \mathrm{~K}$ and $3.5 \mathrm{MPa}$ after $0.7 \mathrm{~s} \mathrm{(a)} \mathrm{and} \mathrm{after} 10 \mathrm{~s} \mathrm{(b)} \mathrm{and} \mathrm{at} 1200 \mathrm{~K}$ and $3.5 \mathrm{MPa}$ after $10 \mathrm{~s} \mathrm{(c)} \mathrm{and} \mathrm{dodecane} \mathrm{pyrolysis} \mathrm{as} \mathrm{a}$ function of time at $1200 \mathrm{~K}$ and $3.5 \mathrm{MPa}(\mathrm{d})$.

Figure 3. Schematic of the permeation test cell with porous medium and associated measures.

Figure 4 Comparison of the numerical / experimental pressure drop as a function of the mass flow rate at $300 \mathrm{~K}$ and $2.5 \mathrm{MPa}$.

Figure 5 Static pressure distribution with streamlines at $300 \mathrm{~K}$ and $2.5 \mathrm{MPa}$ with nitrogen.

Figure 6 Contour of axial velocity and streamlines for dodecane at $300 \mathrm{~K}$ and $3.5 \mathrm{MPa}$.

Figure 7 Species mass fraction (wt. \%) experimentally quantified upstream (HPC), in the porous medium (IPM) and downstream (LPC) during dodecane pyrolysis at $65 \mathrm{mg} . \mathrm{s}-1,3.5 \mathrm{MPa}$ and 820 K.

Figure 8 Minimum (a) and maximum values (b) of the species mass fraction computed numerically as a function of the $\mathrm{x}$-coordinate (in $\mathrm{mm}$ ) for the first case and equivalent data for the second case (c and d).

Figure 9. Comparison of the pyrolysis products composition computed for case 1 and measured experimentally in the HPC (a), inside the porous zone (b) and at the process outlet (c).

Figure $10 \mathrm{C} 12 \mathrm{H} 26$ mass fraction (a), temperature distribution (b), enthalpy of reaction (c) and molecular weight (d) for the two-steps mechanism at $1200 \mathrm{~K}, 3.5 \mathrm{MPa}$ and $60 \mathrm{mg} . \mathrm{s}^{-1}$

Figure 11. Species mass fraction and residence time along the axis of symmetry for the third case at $60 \mathrm{mg} . \mathrm{s}-1$ (a) and the fourth case at $65 \mathrm{mg} . \mathrm{s}-1$ (b).

Figure 12. Dodecane mass fraction inside the system for case 1 (a) and case 4 (b) with residence time and mass fraction distribution along the symmetric $\mathrm{x}$-axis (c).

Figure 13. a: $\mathrm{C} 12 \mathrm{H} 26$ mass fraction in the crosswise direction at the inlet and at the outlet of the porous medium at $1200 \mathrm{~K}, 3.5 \mathrm{MPa}$ and $65 \mathrm{mg} . \mathrm{s}-1$ and b: effect distance from the wall as a function of medium thickness.

Figure 14 Pressure (a), density (b), temperature (c) and axial velocity (d) along $\mathrm{y}$-direction at $\mathrm{x}=$ $0 \mathrm{~mm}$ and $\mathrm{x}=3 \mathrm{~mm}$ at $1200 \mathrm{~K}, 3.5 \mathrm{MPa}$ and $65 \mathrm{mg} . \mathrm{s}-1$.

Figure 15 Temperature (a) and axial velocity (b) along y-direction at $\mathrm{x}=0 \mathrm{~mm}$ and $\mathrm{x}=3 \mathrm{~mm}$ without pyrolysis reactions in the porous medium (1200 K, 3.5 MPa, $65 \mathrm{mg}$.s-1). 
1 Table 1 Reduced kinetic mechanism used in this paper.

2 Table 2 Numerical test conditions for comparison with fluctuating experiments.

3 


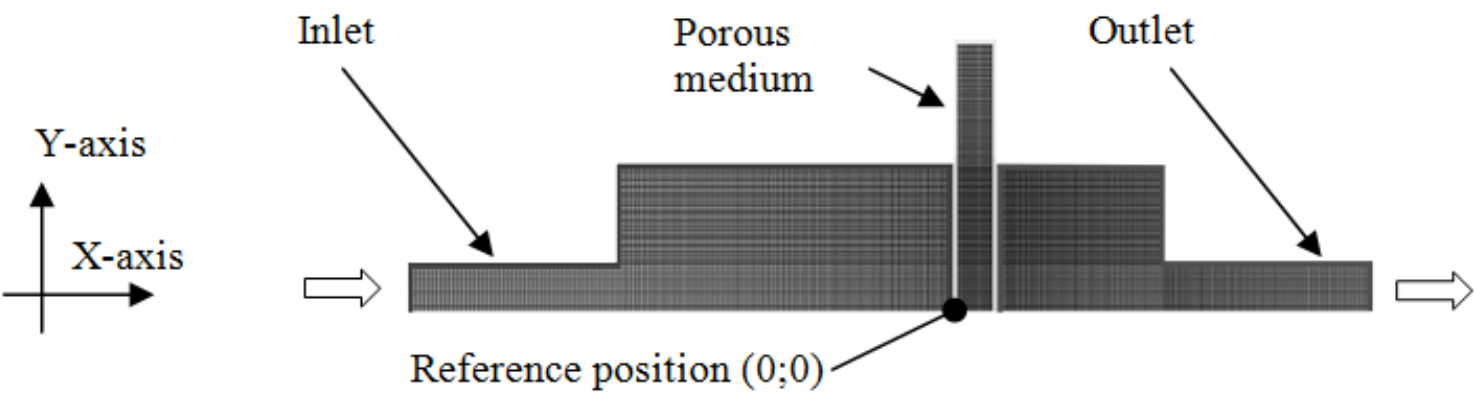

Figure 1 Computational domain layout. 

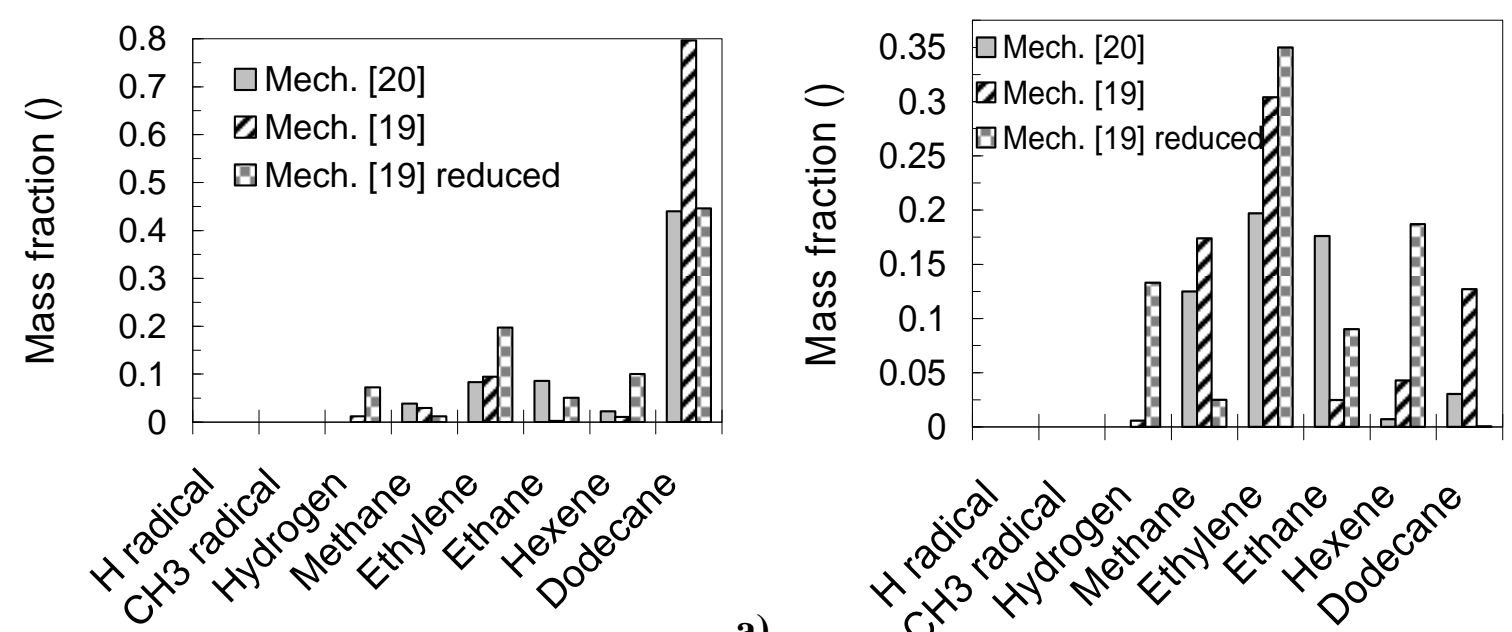

a)

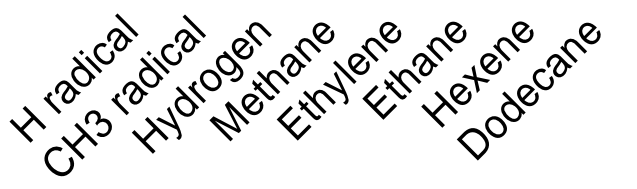

b)
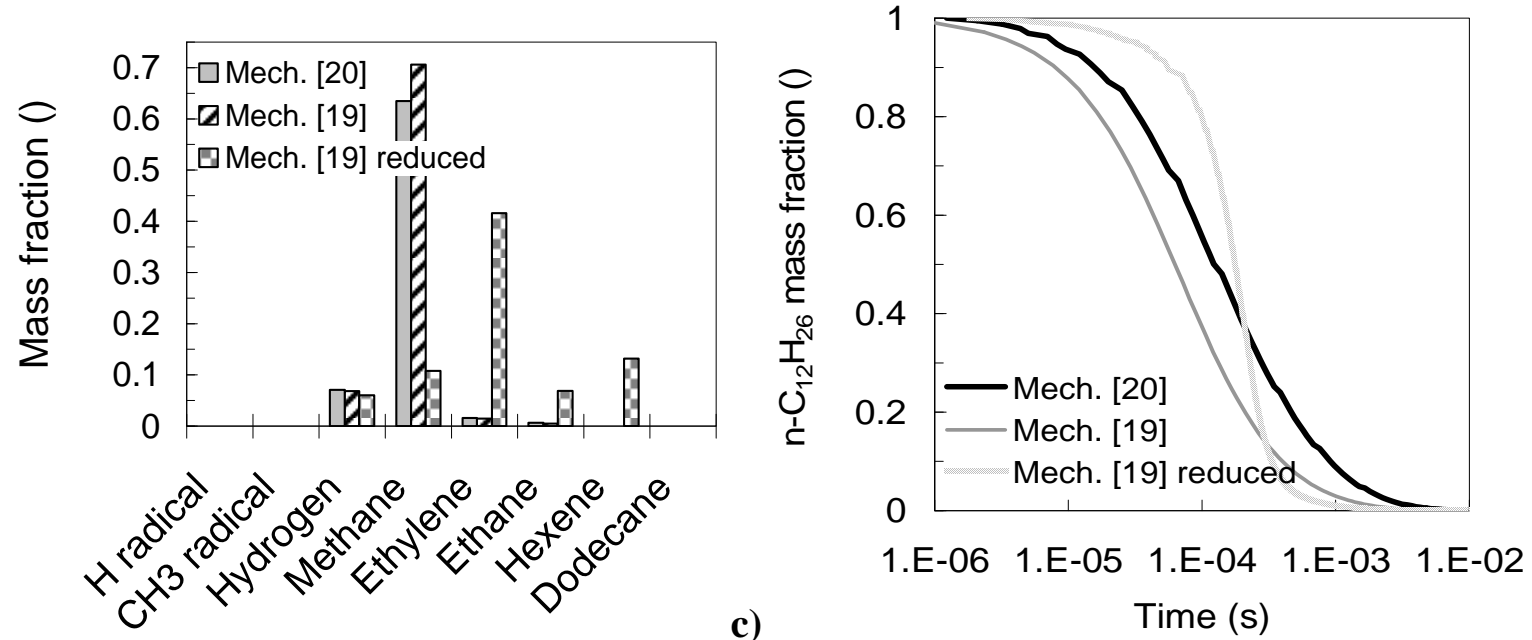

d)

Figure 2. 0-D numerical computations with three kinetic mechanisms at $900 \mathrm{~K}$ and $3.5 \mathrm{MPa}$ after $0.7 \mathrm{~s} \mathrm{(a)}$ and after $10 \mathrm{~s} \mathrm{(b)}$ and at $1200 \mathrm{~K}$ and $3.5 \mathrm{MPa}$ after $10 \mathrm{~s} \mathrm{(c)} \mathrm{and} \mathrm{dodecane}$ pyrolysis as a function of time at $1200 \mathrm{~K}$ and $3.5 \mathrm{MPa}(\mathrm{d})$. 


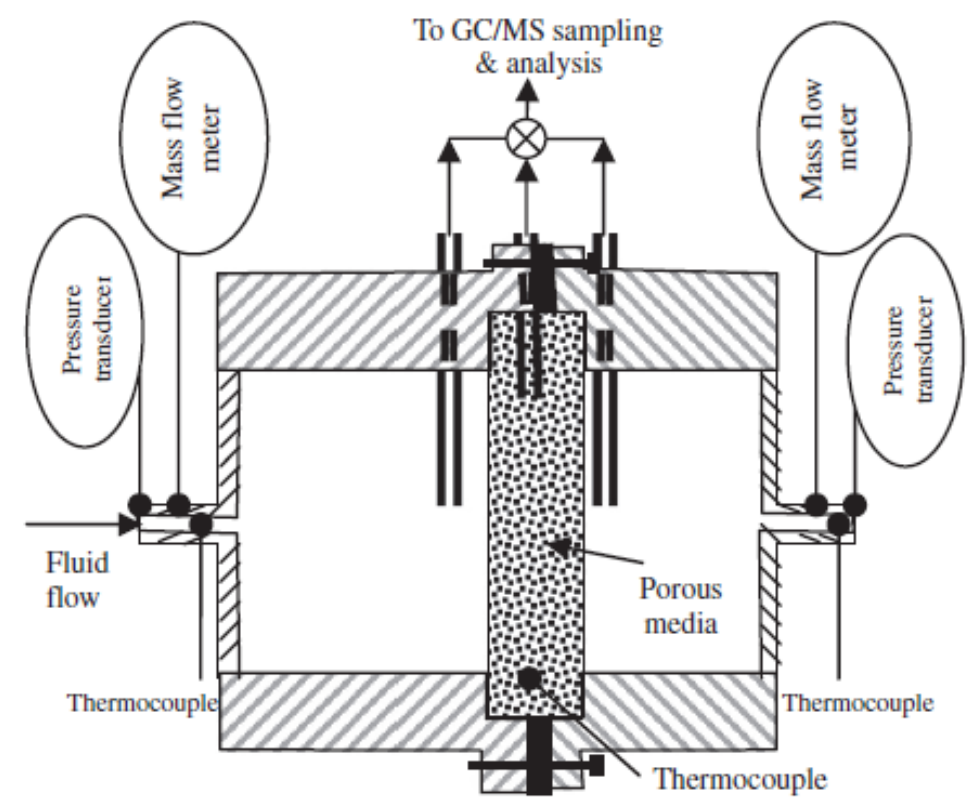

Figure 3. Schematic of the permeation test cell with porous medium and associated measures. 


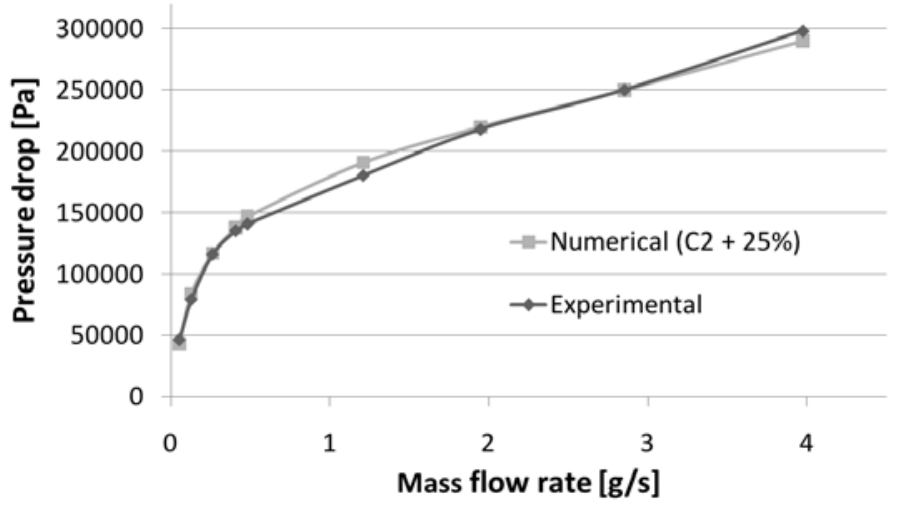

Figure 4 Comparison of the numerical / experimental pressure drop as a function of the mass flow rate at $300 \mathrm{~K}$ and $2.5 \mathrm{MPa}$. 


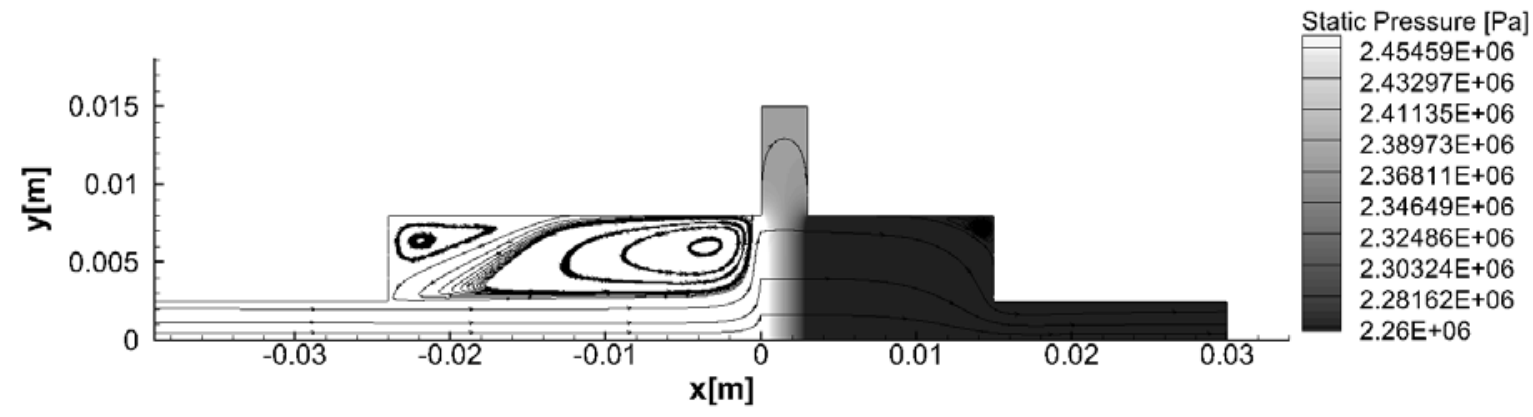

Figure 5 Static pressure distribution with streamlines at $300 \mathrm{~K}$ and $2.5 \mathrm{MPa}$ with nitrogen. 3 


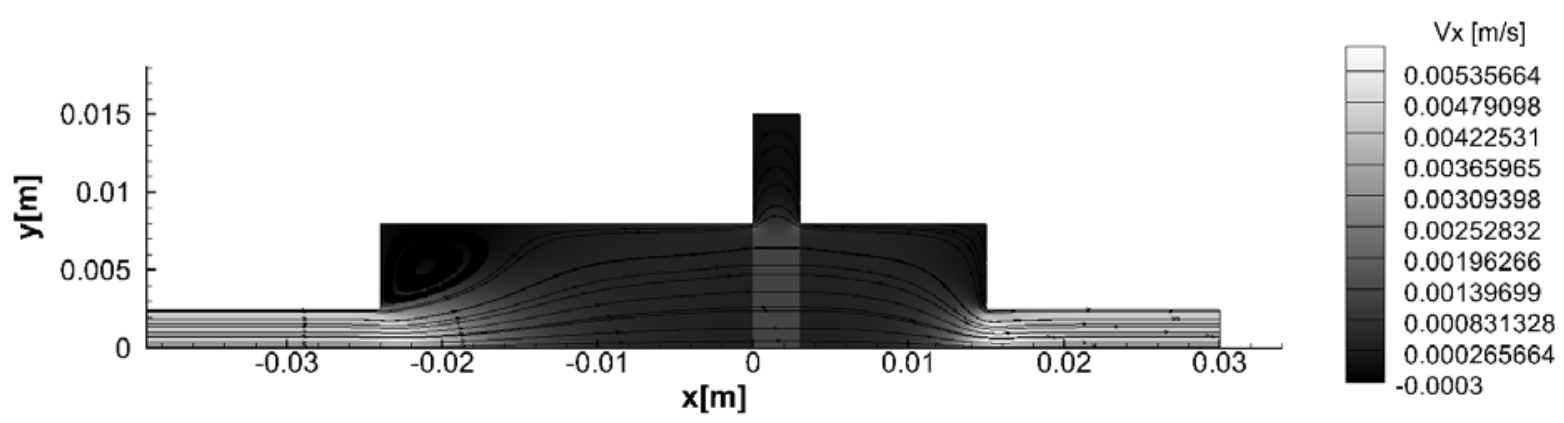

Figure 6 Contour of axial velocity and streamlines for dodecane at $300 \mathrm{~K}$ and $3.5 \mathrm{MPa}$.

3 


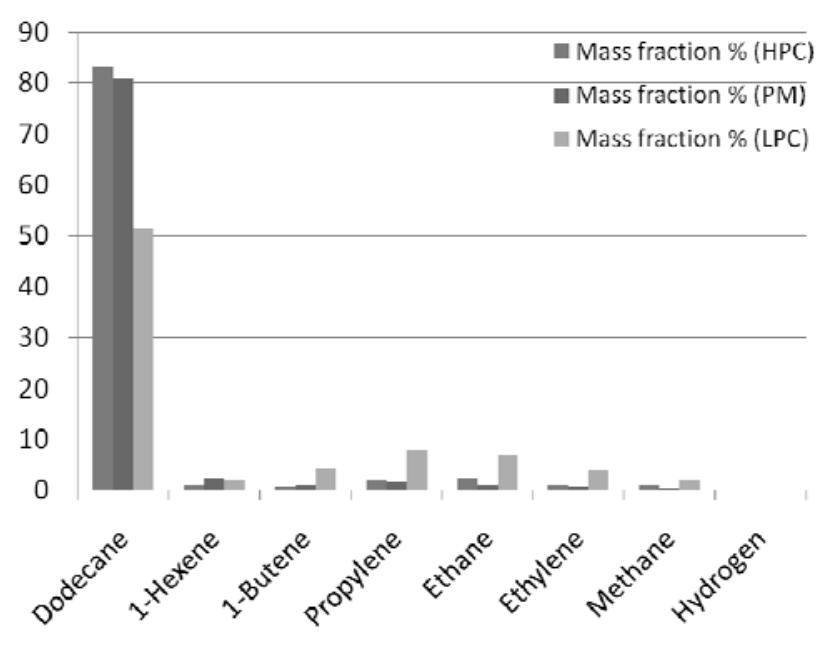

Figure 7 Species mass fraction (wt. \%) experimentally quantified upstream (HPC), in the porous medium (IPM) and downstream (LPC) during dodecane pyrolysis at $65 \mathrm{mg}^{-1}$, $3.5 \mathrm{MPa}$ and $820 \mathrm{~K}$. 

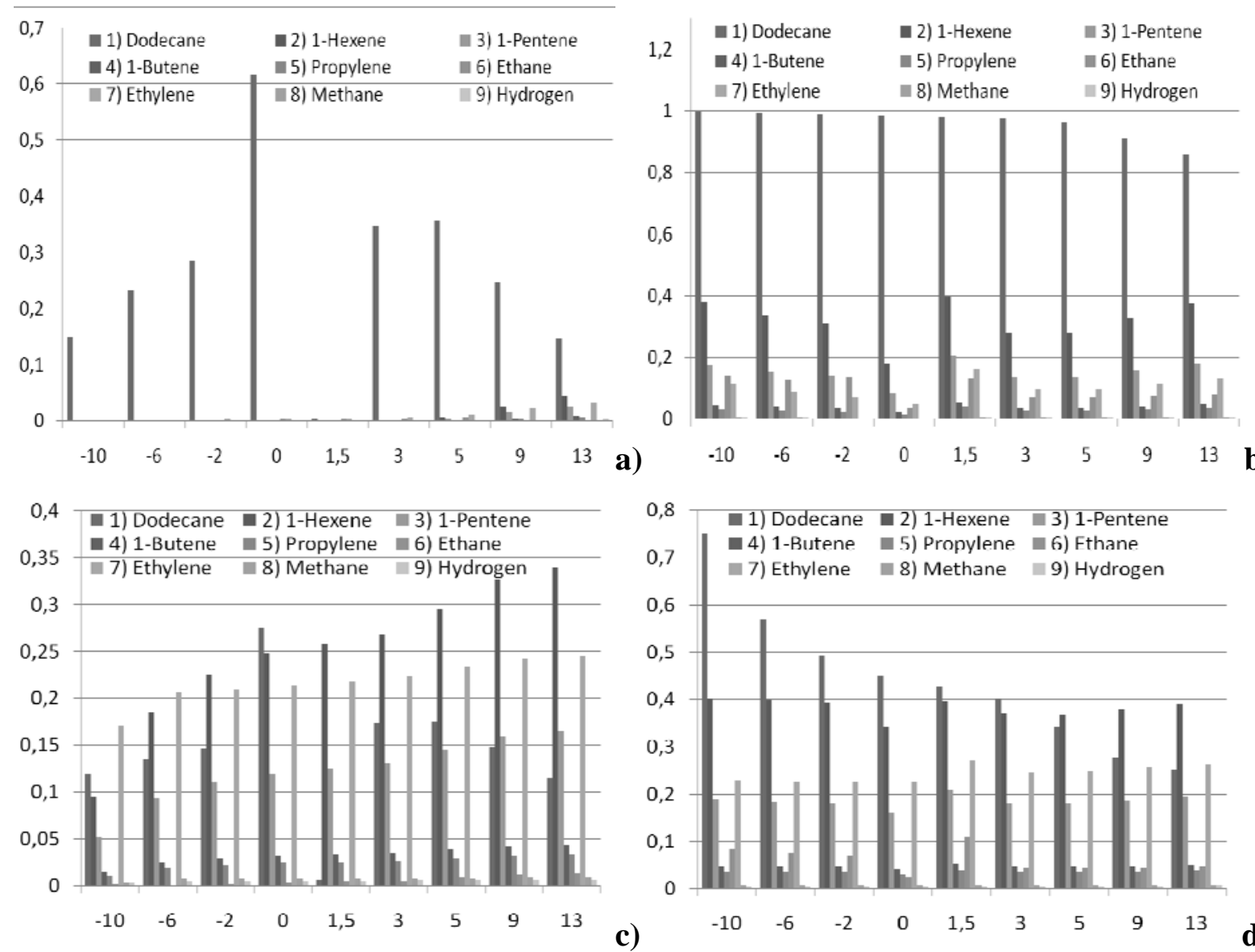

b)

Figure 8 Minimum (a) and maximum values (b) of the species mass fraction computed numerically as a function of the $x$-coordinate (in $\mathbf{~ m m}$ ) for the first case and equivalent data for the second case (c and d). 

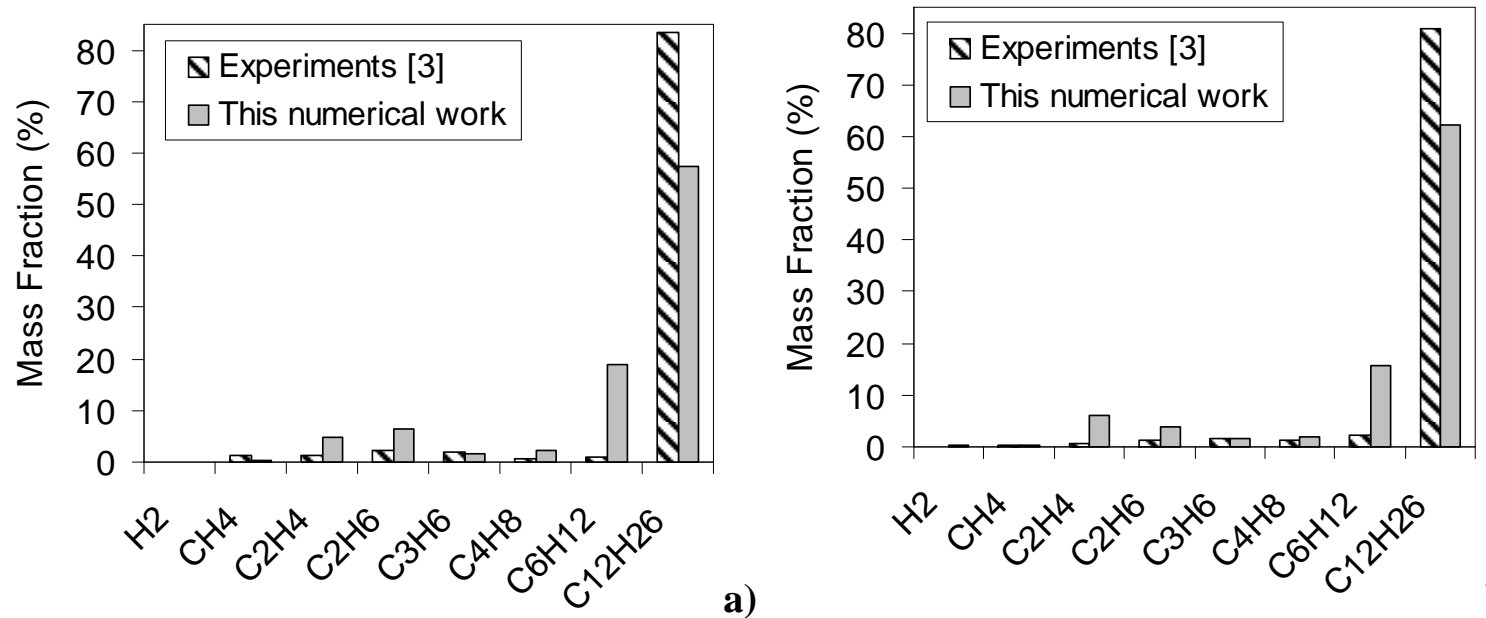

a)

b)

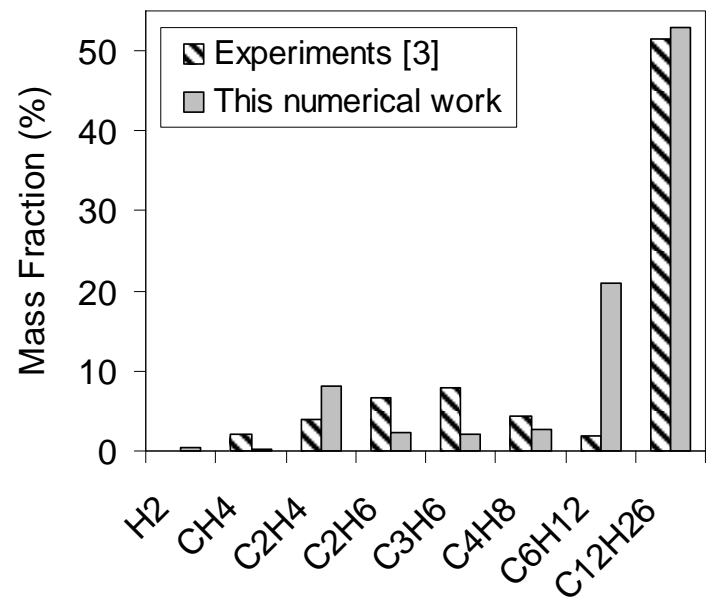

Figure 9. Comparison of the pyrolysis products composition computed for case 1 and measured experimentally in the HPC (a), inside the porous zone (b) and at the process outlet (c). 


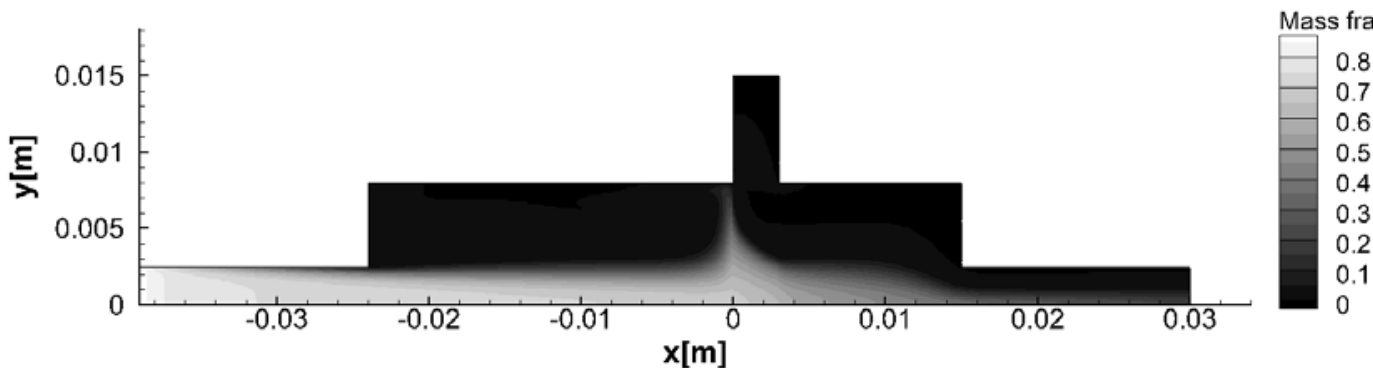

a)

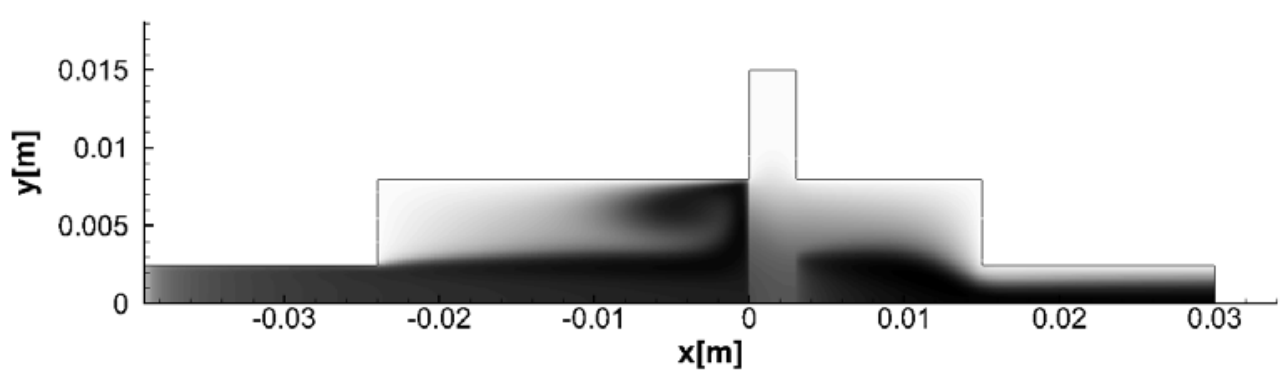

Temperature [K]

- 1184.49

1148.31

1112.12

1075.93

1039.75

1003.56

967.373

931.186

895

b)
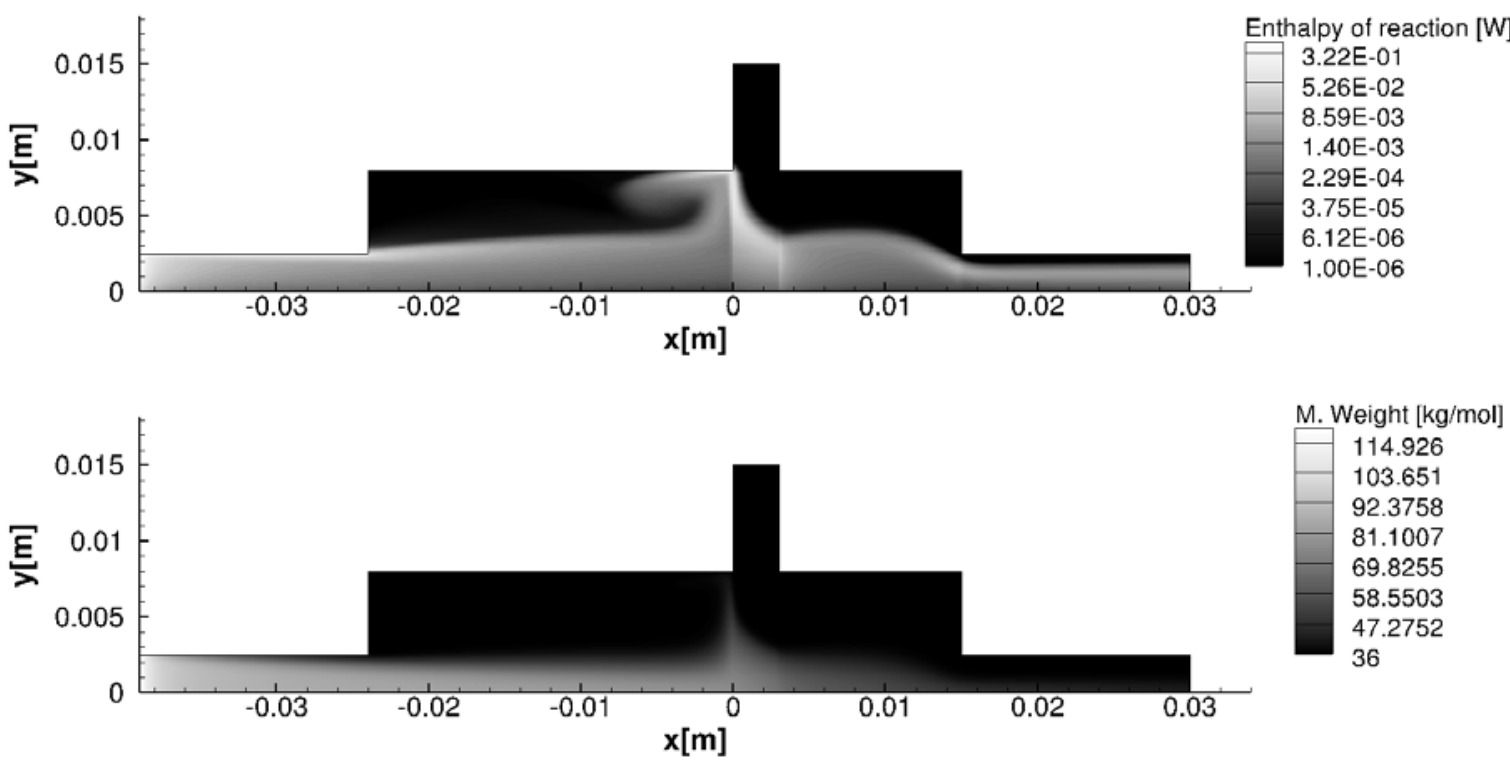

c)

d)

Figure $10 \mathrm{C}_{12} \mathrm{H}_{26}$ mass fraction (a), temperature distribution (b), enthalpy of reaction (c) and molecular weight (d) for the two-steps mechanism at $1200 \mathrm{~K}, 3.5 \mathrm{MPa}$ and $60 \mathrm{mg} . \mathrm{s}^{-1}$ 


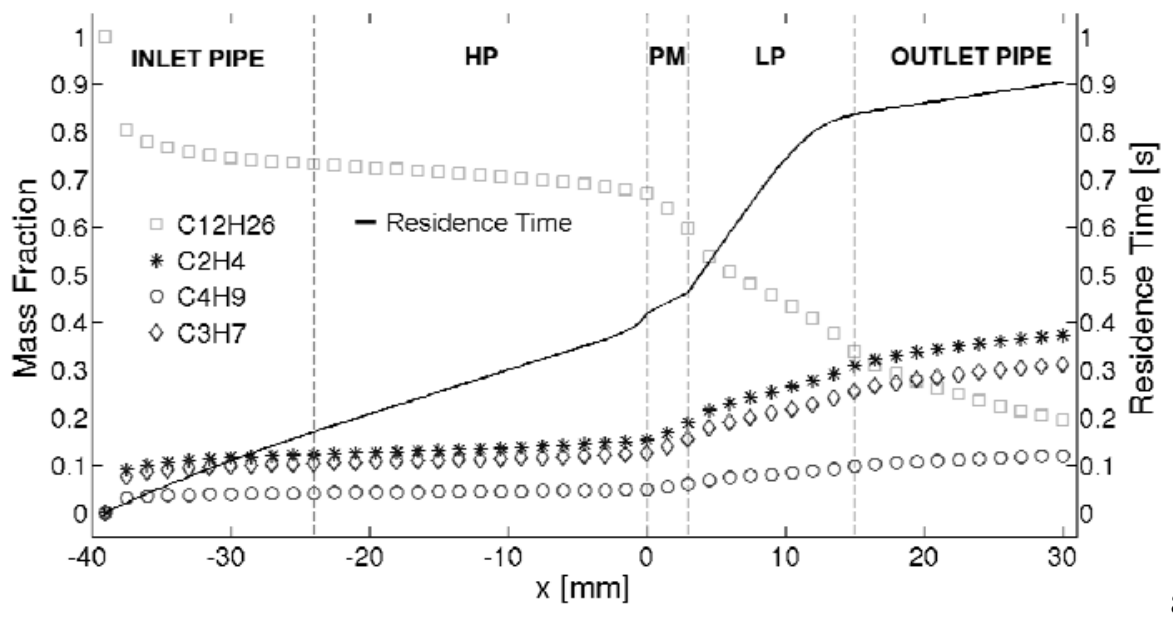

a)

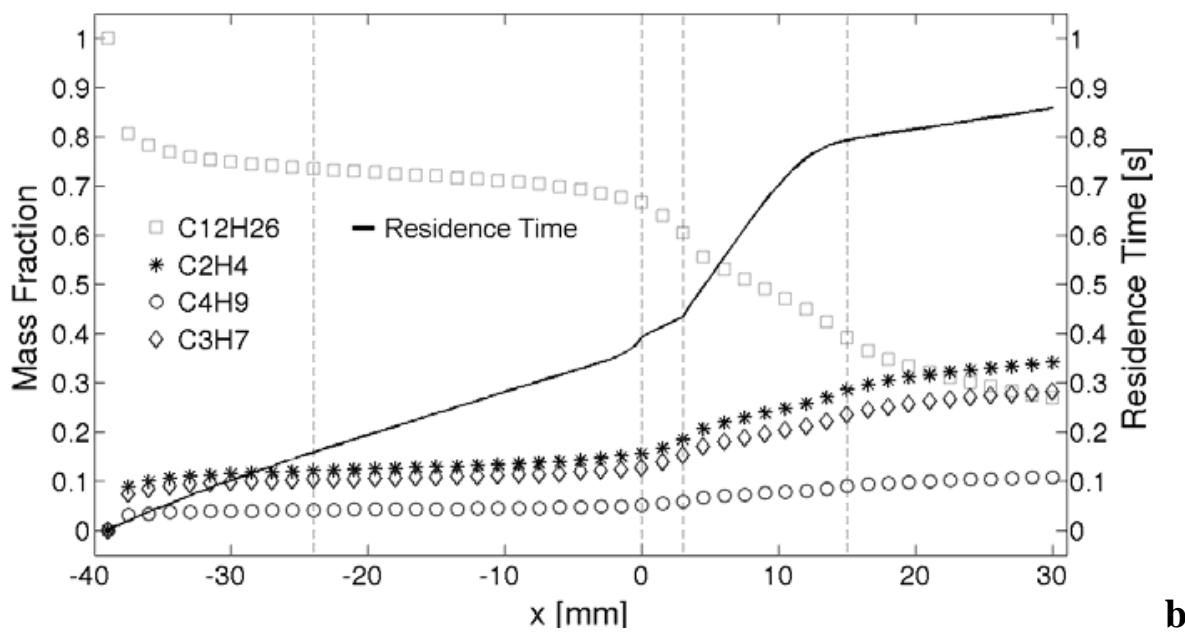

b)

Figure 11. Species mass fraction and residence time along the axis of symmetry for the third case at $60 \mathrm{mg} . \mathrm{s}^{-1}(\mathrm{a})$ and the fourth case at $65 \mathrm{mg}^{-1}{ }^{-1}(\mathrm{~b})$. 


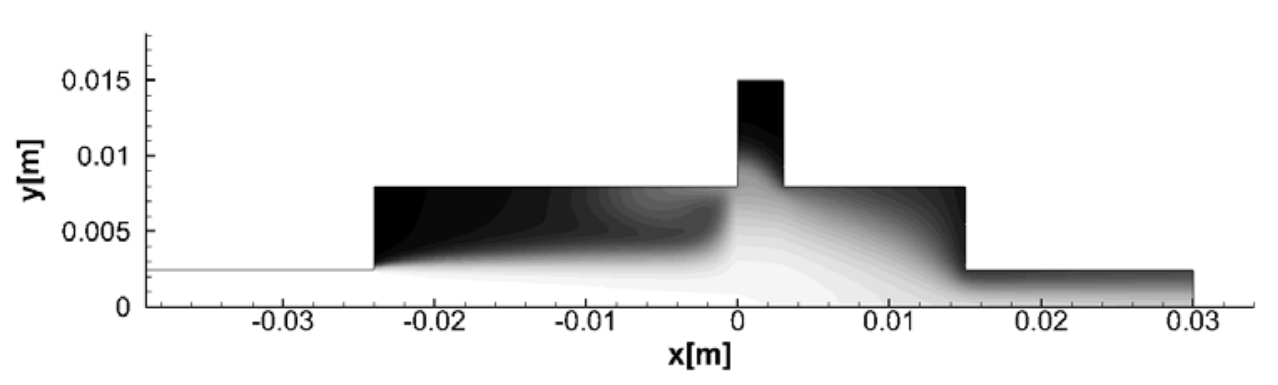

Mass fraction $\mathrm{C}_{12} \mathrm{H}_{26}$
0.980463

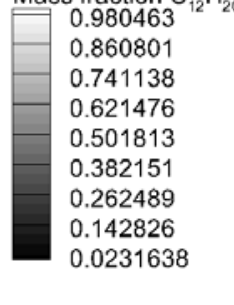

a)

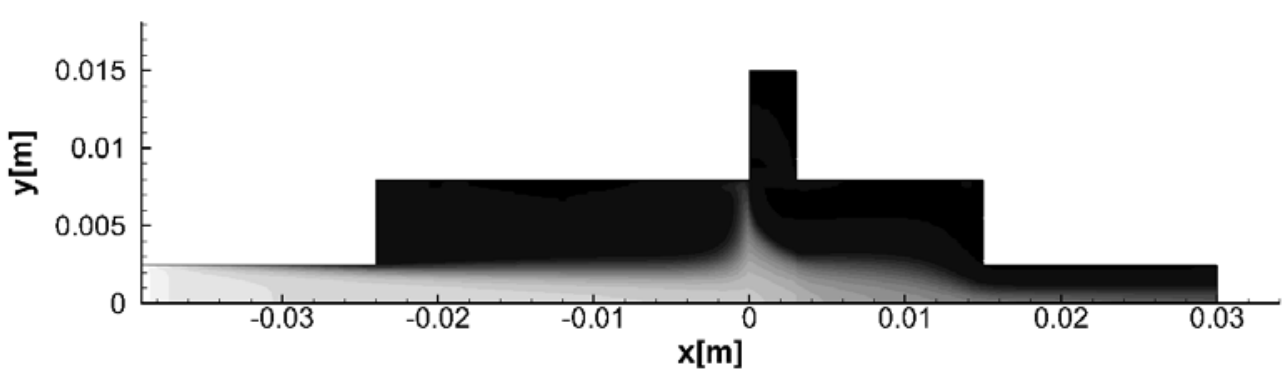

Mass fraction $\mathrm{C}_{12} \mathrm{H}_{20}$

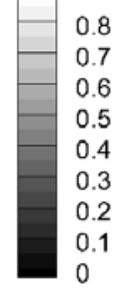

2

$\mathrm{x}[\mathrm{m}]$

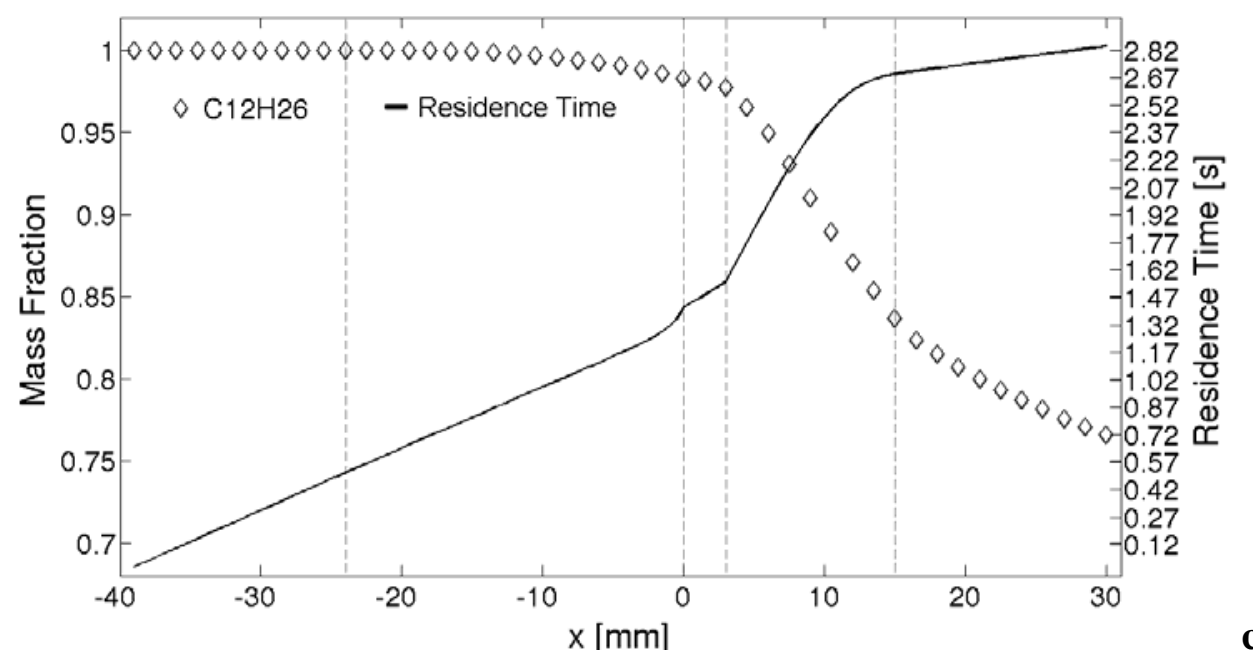

Figure 12. Dodecane mass fraction inside the system for case 1 (a) and case 4 (b) with residence time and mass fraction distribution along the symmetric $x$-axis (c). 

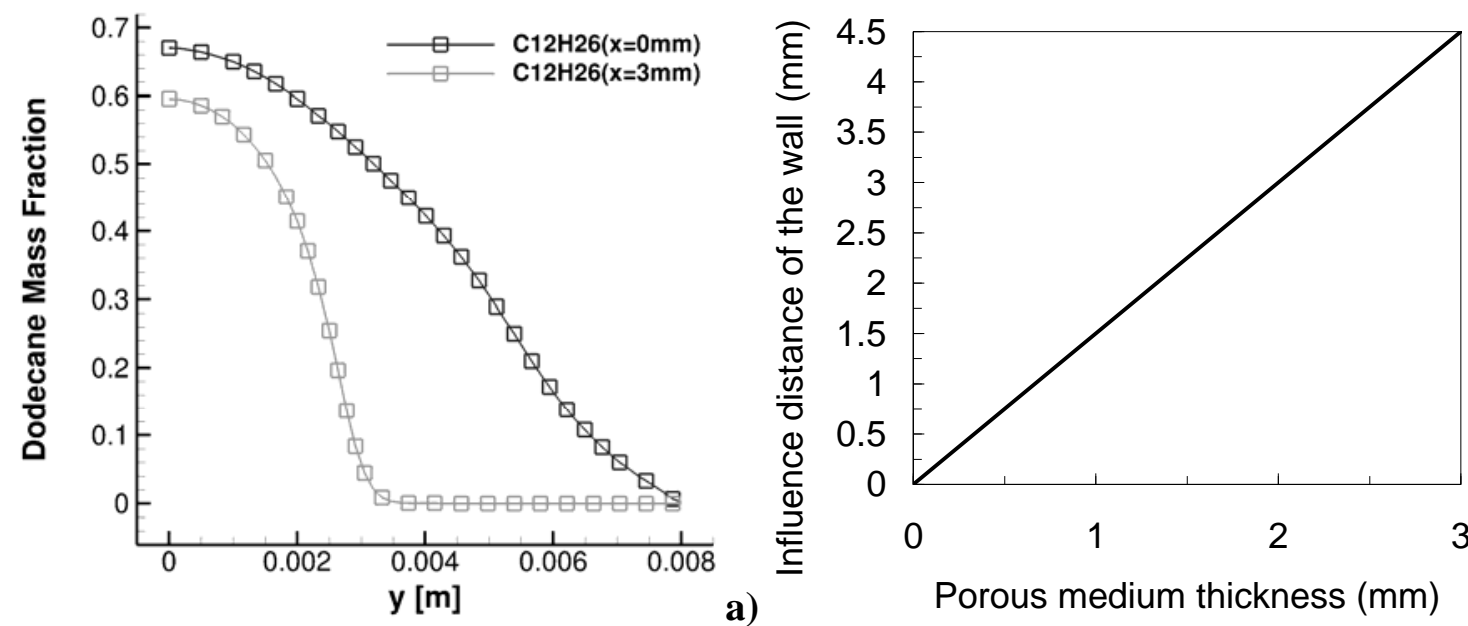

b)

Figure 13. a: $\mathrm{C}_{12} \mathrm{H}_{26}$ mass fraction in the crosswise direction at the inlet and at the outlet of the porous medium at $1200 \mathrm{~K}, 3.5 \mathrm{MPa}$ and $65 \mathrm{mg}^{-1}$ and $\mathrm{b}$ : effect distance from the wall as a function of medium thickness. 

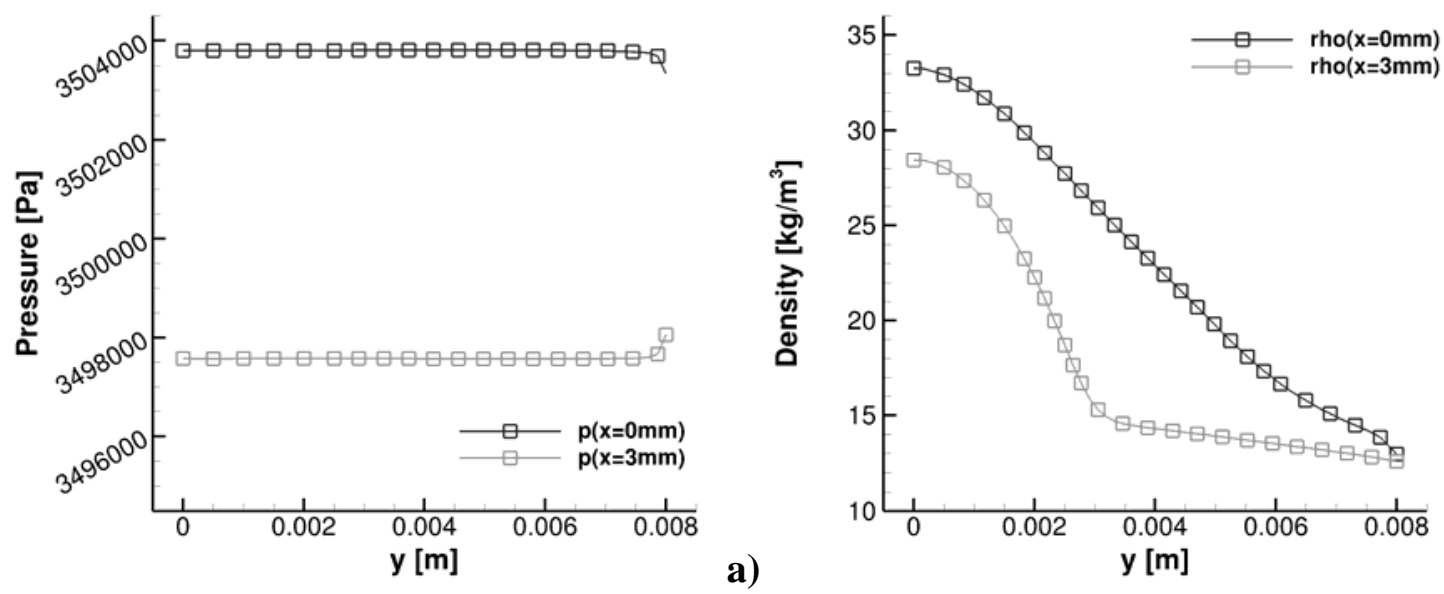

b)
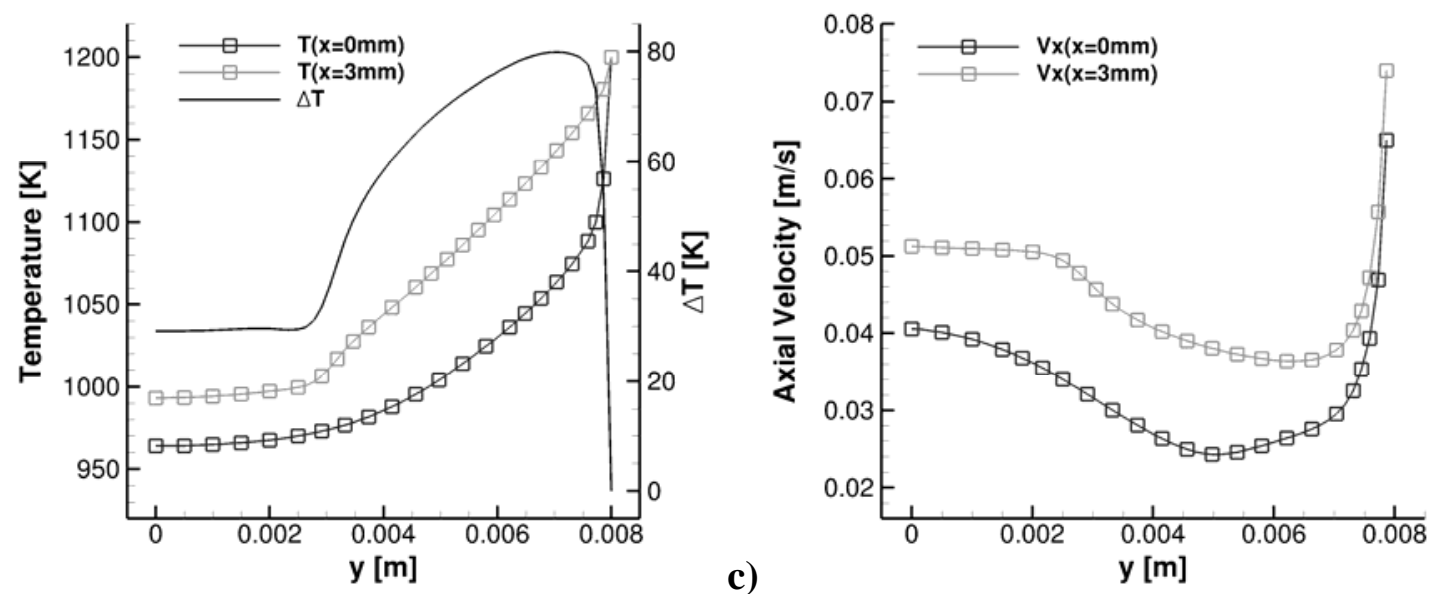

d)

Figure 14 Pressure (a), density (b), temperature (c) and axial velocity (d) along y-direction

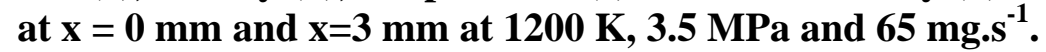



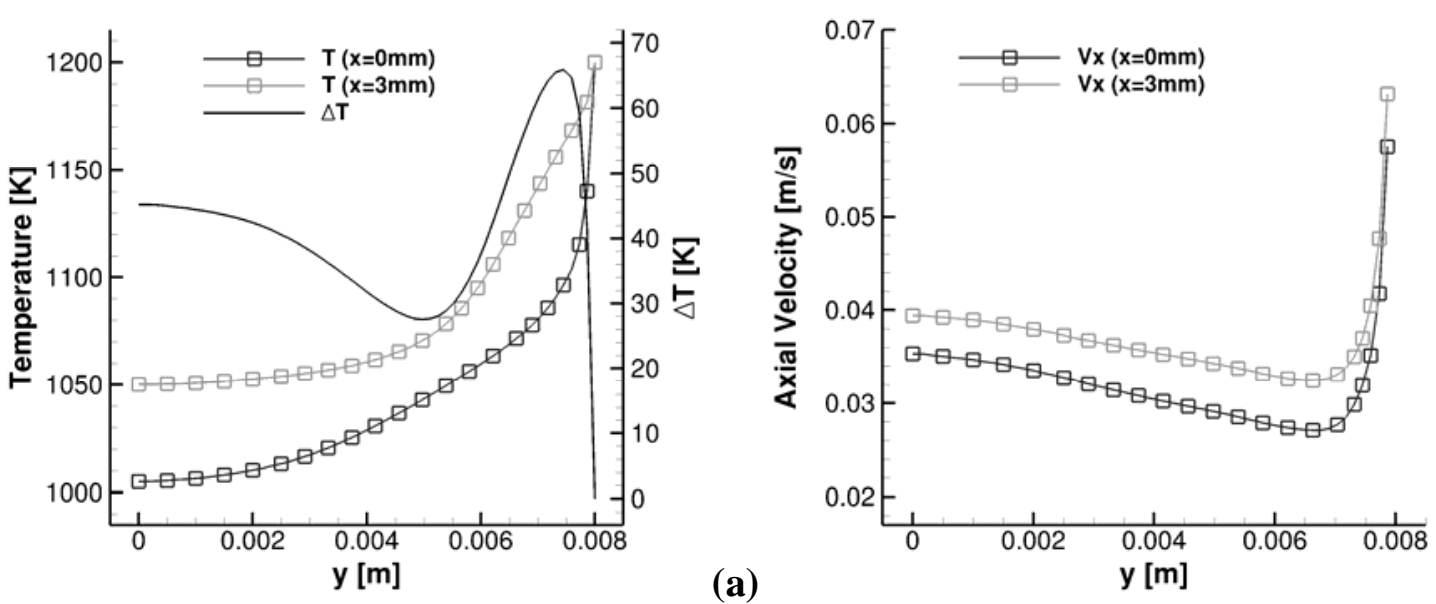

(b)

Figure 15 Temperature (a) and axial velocity (b) along $y$-direction at $x=0 \mathrm{~mm}$ and $x=3$

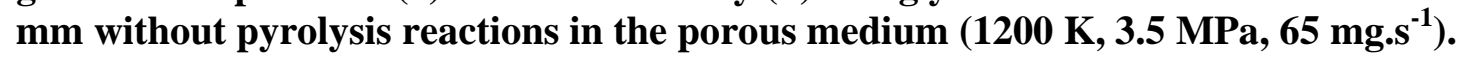


Table 1 Reduced kinetic mechanism used in this paper.

\begin{tabular}{|c|c|c|c|}
\hline [1] & $\mathrm{NC} 12 \mathrm{H} 26=>3 \mathrm{C} 2 \mathrm{H} 4+2 \mathrm{nC} 3 \mathrm{H} 7$ & [12] & $2 \mathrm{CH} 3<=>\mathrm{H}+\mathrm{C} 2 \mathrm{H} 5$ \\
\hline [2] & $\mathrm{NC} 12 \mathrm{H} 26=>2 \mathrm{C} 2 \mathrm{H} 4+2 \mathrm{pC} 4 \mathrm{H} 9$ & [13] & $\mathrm{NC} 12 \mathrm{H} 26+\mathrm{CH} 3=>4 \mathrm{C} 2 \mathrm{H} 4+\mathrm{pC} 4 \mathrm{H} 9+\mathrm{CH} 4$ \\
\hline [3] & $\mathrm{C} 2 \mathrm{H} 4+\mathrm{C} 2 \mathrm{H} 5<=>\mathrm{pC} 4 \mathrm{H} 9$ & [14] & $\mathrm{NC} 12 \mathrm{H} 26+\mathrm{CH} 3=>\mathrm{C} 4 \mathrm{H} 81+2 \mathrm{C} 2 \mathrm{H} 4+\mathrm{pC} 4 \mathrm{H} 9+\mathrm{CH} 4$ \\
\hline [4] & $\mathrm{C} 6 \mathrm{H} 12+\mathrm{H}=\mathrm{C} 2 \mathrm{H} 4+\mathrm{pC} 4 \mathrm{H} 9$ & [15] & $\mathrm{NC12H} 26+\mathrm{CH} 3=>\mathrm{C} 3 \mathrm{H} 6+\mathrm{C} 6 \mathrm{H} 12+\mathrm{nC} 3 \mathrm{H} 7+\mathrm{CH} 4$ \\
\hline [5] & $\mathrm{C} 5 \mathrm{H} 10+\mathrm{H}=\mathrm{C} 2 \mathrm{H} 4+\mathrm{nC} 3 \mathrm{H} 7$ & [16] & $\mathrm{NC} 12 \mathrm{H} 26+\mathrm{CH} 3=>\mathrm{C} 5 \mathrm{H} 10+2 \mathrm{C} 2 \mathrm{H} 4+\mathrm{nC} 3 \mathrm{H} 7+\mathrm{CH} 4$ \\
\hline [6] & $\begin{array}{l}\mathrm{NC} 12 \mathrm{H} 26+\mathrm{H}=> \\
4 \mathrm{C} 2 \mathrm{H} 4+\mathrm{pC} 4 \mathrm{H} 9+\mathrm{H} 2\end{array}$ & [17] & $\mathrm{NC} 12 \mathrm{H} 26+\mathrm{CH} 3=>\mathrm{C} 6 \mathrm{H} 12+\mathrm{C} 2 \mathrm{H} 4+\mathrm{pC} 4 \mathrm{H} 9+\mathrm{CH} 4$ \\
\hline [7] & $\begin{array}{l}\mathrm{NC} 12 \mathrm{H} 26+\mathrm{H}=> \\
\mathrm{C} 4 \mathrm{H} 81+2 \mathrm{C} 2 \mathrm{H} 4+\mathrm{pC} 4 \mathrm{H} 9+\mathrm{H} 2\end{array}$ & [18] & $\mathrm{C} 2 \mathrm{H} 6+\mathrm{CH} 3<=>\mathrm{C} 2 \mathrm{H} 5+\mathrm{CH} 4$ \\
\hline [8] & $\begin{array}{l}\mathrm{NC} 12 \mathrm{H} 26+\mathrm{H}=> \\
\mathrm{C} 3 \mathrm{H} 6+\mathrm{C} 6 \mathrm{H} 12+\mathrm{nC} 3 \mathrm{H} 7+\mathrm{H} 2\end{array}$ & [19] & $\mathrm{CH} 3+\mathrm{CH} 2<=>\mathrm{C} 2 \mathrm{H} 4+\mathrm{H}$ \\
\hline [9] & $\begin{array}{l}\mathrm{NC} 12 \mathrm{H} 26+\mathrm{H}=> \\
\mathrm{C} 5 \mathrm{H} 10+2 \mathrm{C} 2 \mathrm{H} 4+\mathrm{nC} 3 \mathrm{H} 7+\mathrm{H} 2\end{array}$ & [20] & $2 \mathrm{CH} 3(+\mathrm{M})<=>\mathrm{C} 2 \mathrm{H} 6(+\mathrm{M})$ \\
\hline [10] & $\begin{array}{l}\mathrm{NC} 12 \mathrm{H} 26+\mathrm{H}=> \\
\mathrm{C} 6 \mathrm{H} 12+\mathrm{C} 2 \mathrm{H} 4+\mathrm{pC} 4 \mathrm{H} 9+\mathrm{H} 2\end{array}$ & & LOW / 1.7700E+50 $-9.670 \quad 6220.00 /$ \\
\hline \multirow[t]{2}{*}{ [11] } & $2 \mathrm{H}+\mathrm{M}<=>\mathrm{H} 2+\mathrm{M}$ & & $\begin{array}{lllll}\text { TROE/ } & 0.5325 & 151.0 & 1038.0 & 4970.0 / \\
\end{array}$ \\
\hline & $\mathrm{H} 2 / 0.00 /$ & & $\mathrm{H} 2 / 2.00 / \mathrm{CH} 4 / 2.00 / \mathrm{C} 2 \mathrm{H} 6 / 3.00 /$ \\
\hline \multicolumn{4}{|c|}{$\begin{array}{l}\text { Species: n-dodecane, hex-1-ene, pent-1-ene, but-1-ene, propylene, ethane, ethylene, methane, } \\
\text { tripet-methylene }\end{array}$} \\
\hline
\end{tabular}


Table 2 Numerical test conditions for comparison with fluctuating experiments.

\begin{tabular}{ccccc}
\hline \hline & $\begin{array}{c}\text { Inlet fluid } \\
\text { temperature } \\
(\mathrm{K})\end{array}$ & $\begin{array}{c}\text { Inlet pipe } \\
\text { temperature }\end{array}$ & $\begin{array}{c}\text { Walls of the test cell } \\
(\text { except inlet pipe })\end{array}$ & $\begin{array}{c}\text { Fuel Mass flow rate } \\
\left(\mathrm{mg} . \mathrm{s}^{-1}\right)\end{array}$ \\
\hline Case 1 & 820 & 820 & $(\mathrm{~K})$ & 65 \\
Case 2 & 890 & 890 & 890 & 60 \\
Case 3 & 1200 & 1200 & 890 & 60 \\
Case 4 & 1200 & 1200 & 1200 & 65 \\
\hline \hline
\end{tabular}

2 